\title{
Alkaline Replenisher Evaluation for Printed Wiring Board Fabrication
}

Federal Manufacturing \& Technologies

D. R. Tucker and S. E. Goldammer

KCP-613-5916

Published April 1997

Topical Report
PECETE

MA1 131837

051

Approved for public release; distribution is unlimited.

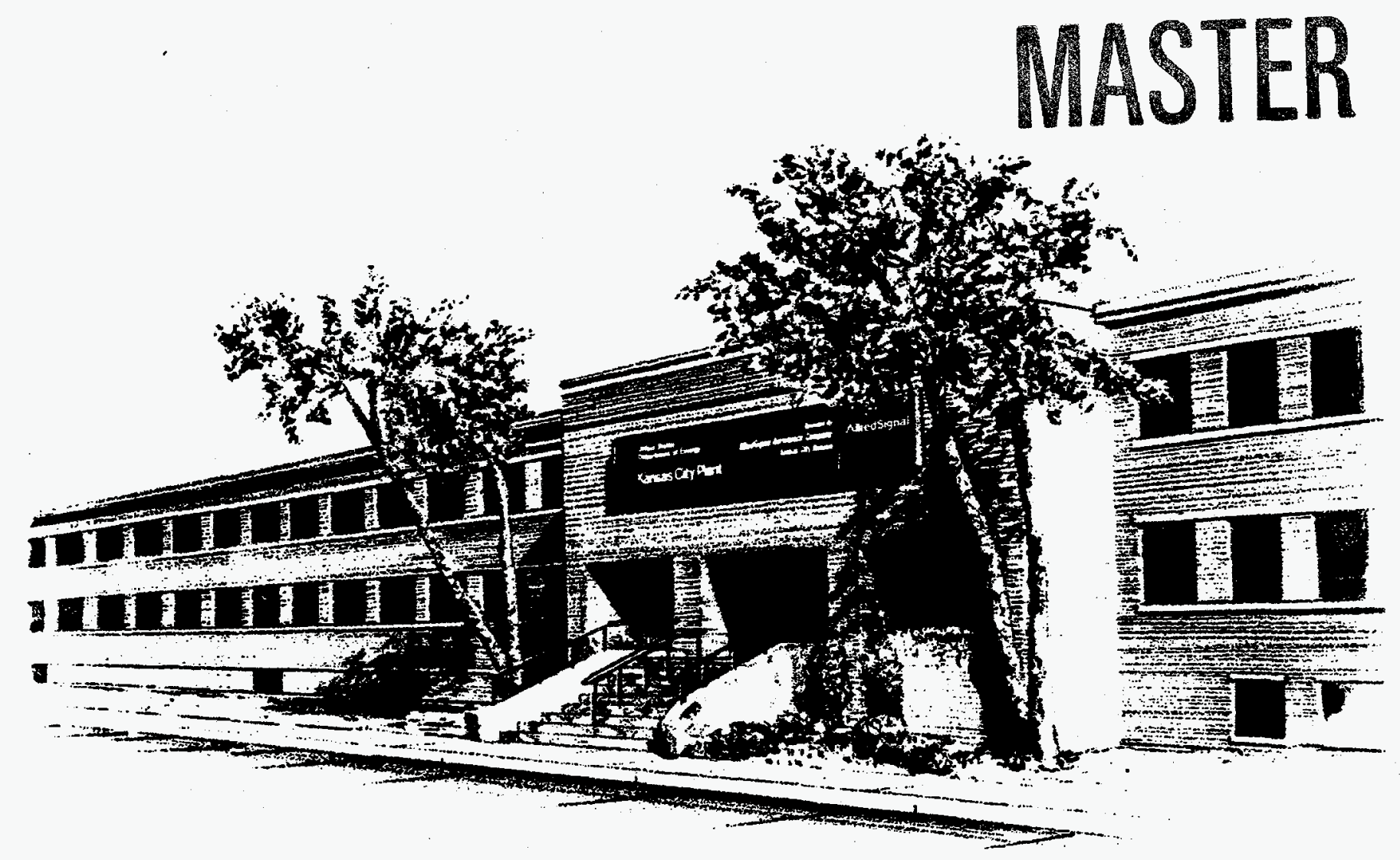




\section{DISCLAIMER}

This report was prepared as an account of work sponsored by an agency of the United States Government. Neither the United States Government nor any agency thereof, nor any of their employees, makes any warranty, express or implied, or assumes any legal liability or responsibility for the accuracy, completeness, or usefulness of any information, apparatus, product, or process disclosed, or represents that its use would not infringe privately owned rights. Reference herein to any specific commercial product, process, or service by trade names, trademark, manufacturer, or otherwise, does not necessarily constitute or imply its endorsement, recommendation, or favoring by the United States Government or any agency thereof. The views and opinions of authors expressed herein do not necessarily state or reflect those of the United States Government or any agency thereof.

All data prepared, analyzed and presented has been developed in a specific context of work and was prepared for internal evaluation and use pursuant to that work authorized under the referenced contract. Reference herein to any specific commercial product, process or service by trade name, trademark, manufacturer, or otherwise, does not necessarily constitute or imply its endorsement, recommendation, or favoring by the United States Government, any agency thereof or AlliedSignal Inc.

Printed in the United States of America.

This report has been reproduced from the best available copy.

Available to DOE and DOE contractors from the Office of Scientific and Technical Information, P. O. Box 62, Oak Ridge, Tennessee 37831; prices available from (615) 576-8401, FTS 626-8401.

Available to the public from the National Technical Information Service, U. S. Department of Commerce, 5285 Port Royal Rd., Springfield, Virginia 22161.

A prime contractor with the United States Department of Energy under Contract Number DE-ACO4-76-DP00613.
AlliedSignal Inc. Federal Manufacturing \& Technologies P. O. Box 419159 Kansas City, Missouri $64141-6159$ 


\section{DISCLAIMER}

This report was prepared as an account of work sponsored by an agency of the United States Government. Neither the United States Government nor any agency thereof, nor any of their employees, make any warranty, express or implied, or assumes any legal liability or responsibility for the accuracy, completeness, or usefulness of any information, apparatus, product, or process disclosed, or represents that its use would not infringe privately owned rights. Reference herein to any specific commercial product, process, or service by trade name, trademark, manufacturer, or otherwise does not necessarily constitute or imply its endorsement, recommendation, or favoring by the United States Government or any agency thereof. The views and opinions of authors expressed herein do not necessarily state or reflect those of the United States Government or any agency thereof. 


\section{DISCLAMMER}

Portions of this document may be illegible in electronic image products. Images are produced from the best available original document. 
KCP-613-5916

Distribution Category UC-706

Approved for public release; distribution is unlimited.

\section{ALKALINE REPLENISHER EVALUATION FOR PRINTED WIRING BOARD FABRICATION \\ D. R. Tucker and S. E. Goldammer}

Published April 1997

Topical Report

Project Team:

Cheryl Brown

Steve Goldammer

Larry Lantz

Harry Linn

Tom Livengood

Michelle Maurer

Charlie Paith

Susan Pemberton

Chuck Stimetz

Don Tucker

Tom Washington

Dan Williams

Ray Latize, MacDermid Incorporated 


\section{Contents}

Section

Page

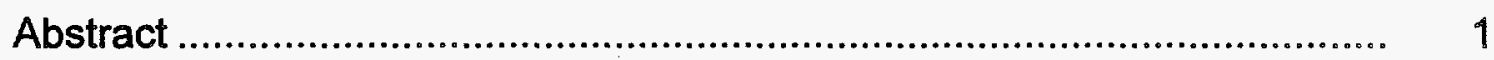

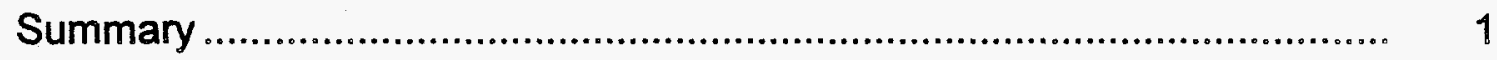

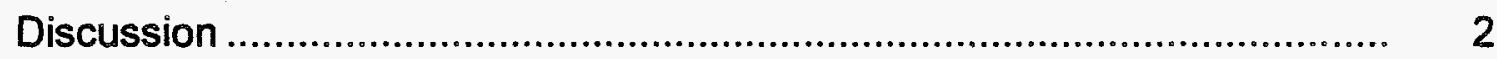

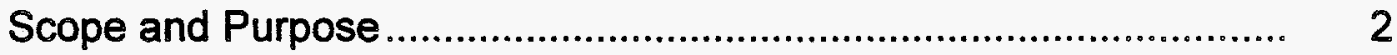

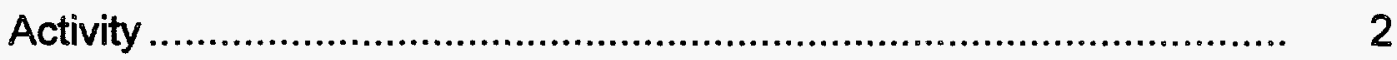

Background ....................................................................... 2

Evaluation ........................................................................ 4

Accomplishments ................................................................ 13

Appendices

A. Conductor Analysis Test Artwork ........................................... 14

B. Tool-Made Sample Artwork ................................................... 16

C. Test Panel Processing Sequence ............................................. 18

D. Conductor Analysis Test Artwork 5 to 8 Mil Lines ..................... 20

E. Panel Numbering and Description .......................................... 22

F. Conductor Analysis Electrical Test Results ............................... 24 


\section{Illustrations}

$\begin{array}{ll}\text { Figure Page } & \text { Page }\end{array}$

1 Process Flow Diagram of the Alkaline Etch Process ....................... 3

2 Diagram of the Alkaline Etch Process (Chemcut Model 547)............ 4

\section{Tables}

Number

1 Comparison of Ultra Etch Aqueous, Ultra Etch FL, and Ultra Etch 50 .

2 Chemical Analysis Prior to Etching Panels.

3 Comparison of Chemcut and Atotech System Operating Parameters

4 Comparison of Chemcut and Atotech System Nozzle Configuration

5 Chemical Analysis of the Ultra Etch FL and Ultra Etch Variations...... 8

$6100 \%$ Ultra Etch FL and Chem 3 Analysis .................................. 9

$7 \quad 50 \%$ Ultra Etch FL and Chem 3 Analysis .................................. 9

$825 \%$ Ultra Etch FL and Chem 3 Analysis .................................. 10

$95 \%$ Ultra Etch FL, Chem 3, and FRM Analysis.......................... 11

10 Electrical Test Data of Panels Etched at a Speed of 53 Inches Per Minute

11 Electrical Test Data of Panels Etched at a Speed of 60 Inches Per Minute 


\section{Abstract}

An alkaline chemistry and modifications of the chemistry were evaluated for use in a flood rinse module during alkaline etching of printed wiring boards.

\section{Summary}

MacDermid's Metex Ultra Etch FL and modifications to the Ultra Etch FL chemistry were evaluated as replacements of a discontinued replenisher, Uitra Etch Aqueous. Ultra Etch FL with additions of water to lower the total alkalinity and ammonium chloride to maintain the chloride level was found to produce acceptable results and, in fact, had a similar chemical composition to Ultra Etch Aqueous. 


\section{Discussion}

\section{Scope and Purpose}

Ultra Etch FL, a proprietary alkaline etch replenisher and modifications of Ultra Etch FL were evaluated for the alkaline etch process in the Printed Circuit Boards Fabrication Department. The flood rinse module replenisher was used to

1. rinse off etch residues as printed circuit boards exited the main etch sump and

2. overflow into the main etch sump to help maintain the chemical balance of the etch solution.

This evaluation was needed to find a suitable replacement flood rinse module chemistry for the etch process because the production replenisher, MacDermid's Ultra Etch Aqueous, was no longer going to be manufactured.

\section{Activity}

\section{Background}

Photoresists used in the printed wiring board fabrication processes to protect copper circuits during the etch process were sensitive to alkaline chemistries. In fact, following the etch process, an alkaline chemistry ( $\mathrm{pH}$ between 10.5 and 14.0) was used to remove (strip) the photoresist.

Ammoniacal copper chloride, an alkaline chemistry ( $\mathrm{pH}$ between 7.6 and 7.8 ), was used to etch the copper areas adjacent to the photoresist-covered circuit patterns. The chemistry pH in the etching process had to be high enough for efficient copper etching, but not so high that the chemistry would damage the photoresist. As the etch bath was used, the copper content, chloride content, and $\mathrm{pH}$ changed. The $\mathrm{pH}$ lowered during the etch process but was maintained with additive chemistries such as ammonium hydroxide and proprietary replenishers (which were also used to maintain copper and chloride content). As circuit boards exited the etch module, they entered the flood rinse module, where a replenisher chemistry was "flooded" onto the printed circuit boards to remove any active etch residues.

\section{A diagram of the alkaline process flow is shown in Figure 1.}

Two alkaline replenishers were used during the etch process, MacDermid's Ultra Etch 50 and MacDermid's Ultra Etch Aqueous. MacDermid's Ultra Etch 50 had a slightly higher pH ( $\mathrm{pH}$ between 9.0 and 10.0) than the Ultra Etch Aqueous ( $\mathrm{pH}$ between 8.0 and 9.0). Ultra Etch 50 was pumped directly into the etch sump to help maintain the etch chemistry. Although the pH of Ultra Etch 50 was high enough to damage the photoresist, this replenisher was mixed with the large volume of low pH etch chemistry before being directly sprayed onto the printed circuit boards. 


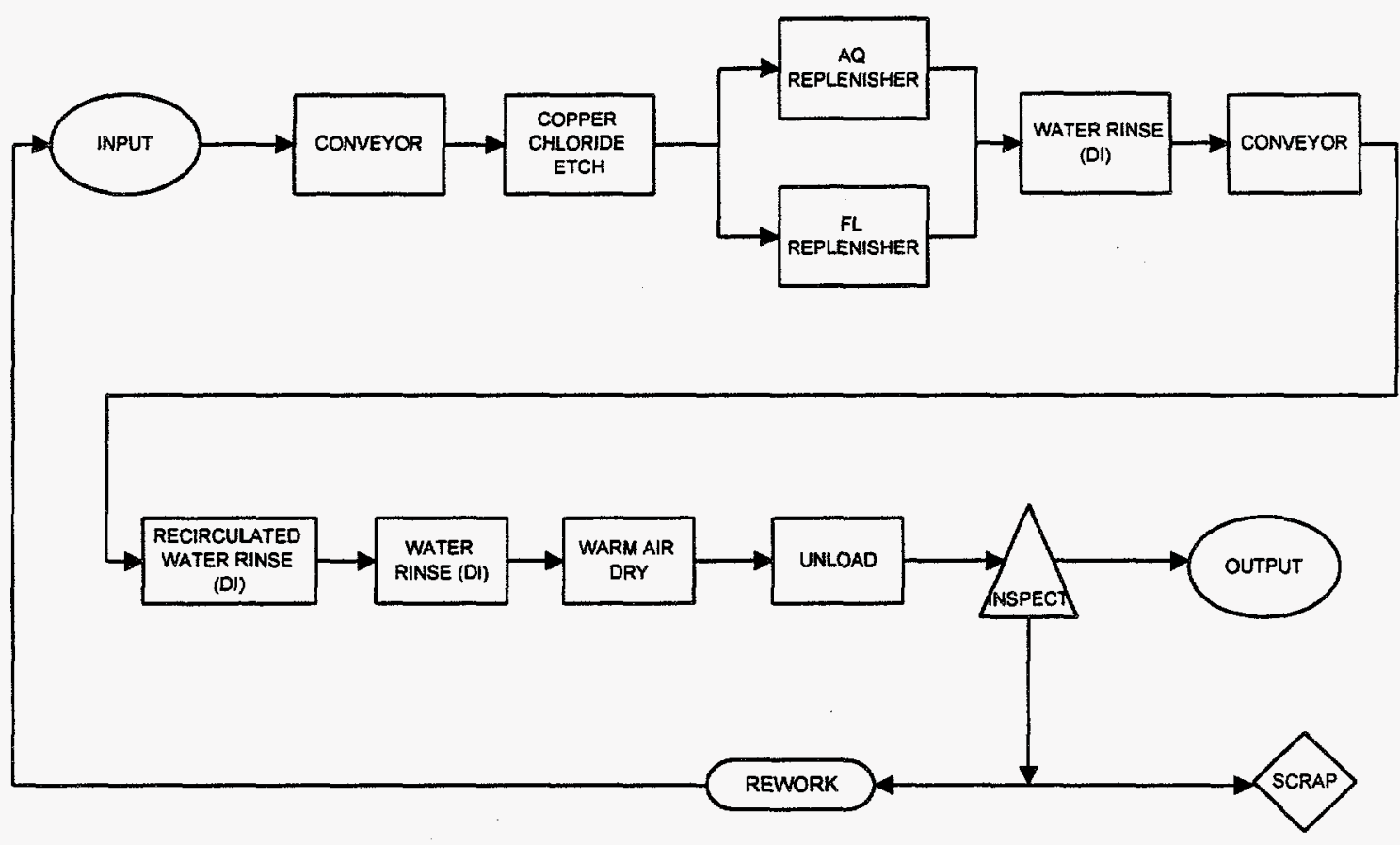

Figure 1. Process Flow Diagram of the Alkaline Etch Process

Used or "spent" etch solution was pumped from the etch sump to the spent barrel. As the product left the etch module, it entered the flood rinse modules where the flood rinse chemistry was "flooded" directly onto the product.

Two etch systems were used during this evaluation. One was a Chemcut Model 547, and the other was an Atotech Sigma Series etcher. The Chemcut system had two flood rinse modules and the Atotech system had three. In both systems, dragout from the etch module was introduced into the first flood rinse module as panels traveled through the system. Likewise, dragout from the first flood rinse module was introduced into the second flood rinse module, and dragout from the second was introduced into the third flood rinse module (Atotech system). Because of the dragout phenomenon, the fresh flood rinse chemistry was pumped directly into the last flood rinse module, which overflowed into the preceding flood rinse module(s), which overflowed into the etch sump.

The incoming fresh flood rinse replenisher came in direct contact with the product. In order to prevent damage to the photoresist, the Ultra Etch Aqueous with its low pH and total alkalinity was used for flood rinsing. A diagram of the etch line which shows the addition and removal of etch chemistries is shown in Figure 2.

In the summer of 1995, AlliedSignal Federal Manufacturing and Technologies (FM\&T) plant in Kansas City, Missouri, was informed that MacDermid, the supplier of Ultra Etch Aqueous replenisher, would no longer be making Ultra Etch Aqueous. Printed wiring board (PWB) engineers contacted MacDermid regarding a recommended replacement. MacDermid recommended Ultra Etch FL with a pH between 8.5 and 9.5. MacDermid also suggested using the Ultra Etch 50 in the flood rinse module as well as in the main etch sump but lowering the Ultra Etch 50's $\mathrm{pH}$ prior to entering the flood rinse module. 
DIRECTION OF PANEL FLOW

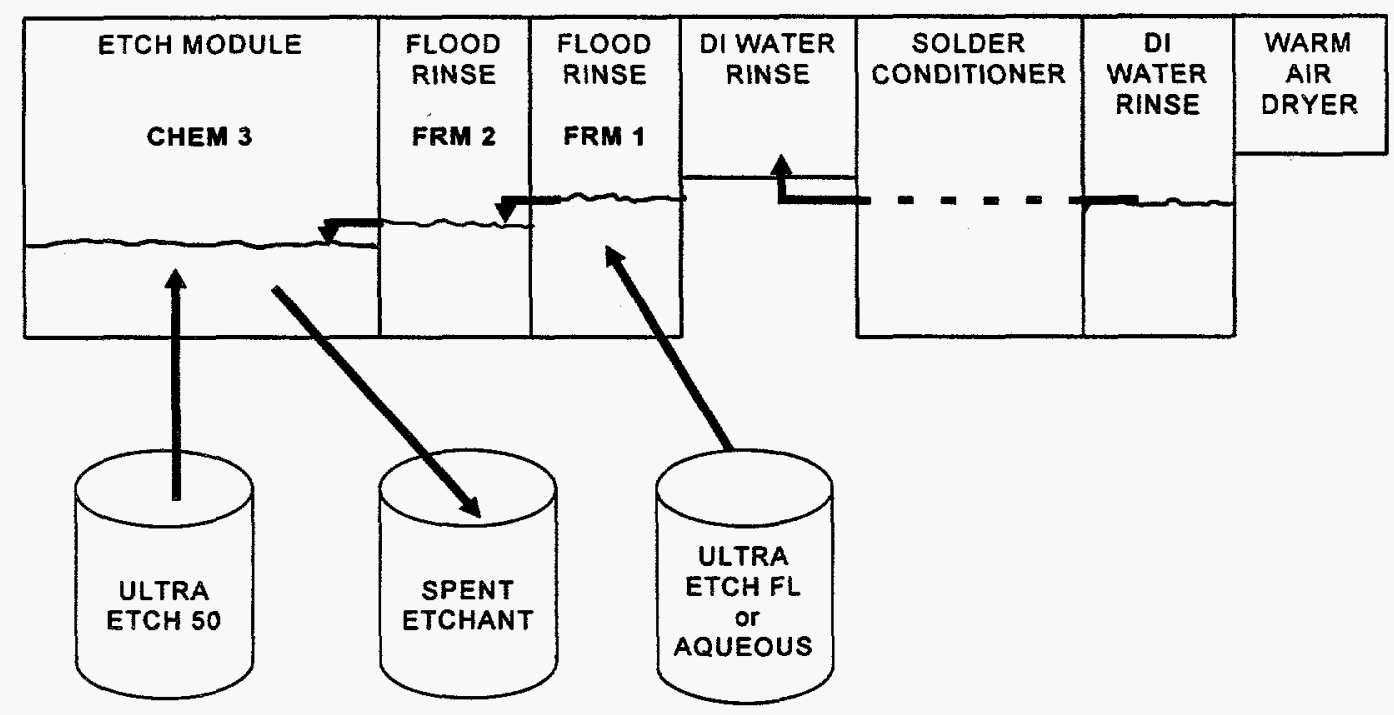

Figure 2. Diagram of the Alkaline Etch Process (Chemcut Model 547)

Ultra Etch FL (FL stands for fine lines) was previously evaluated along with Ultra Etch Aqueous during the solvent-to-aqueous processing studies in the late 1980s at FM\&T. The Ultra Etch FL was advertised as producing better sidewalls in etched copper features and, as a result, was the preferred replenisher for etching patterns with fine lines and spaces ( $<0.005^{\prime \prime}$ in width). Ultra Etch FL, however, had a slightly higher pH $(7.6-8.4)$ than the Ultra Etch Aqueous (advertised $\mathrm{pH}$ at that time was between $7.6-8.0$ ) and was more expensive. For the FM\&T circuit line and space width requirements during the time of the initial study, the etch quality between the Ultra Etch FL and Ultra Etch aqueous was insignificant. The Ultra Etch Aqueous was chosen as the replenisher because it produced acceptable results, was less expensive, and was not as likely to degrade the photoresist due to its lower $\mathrm{pH}$, thereby increasing the processing latitude.

\section{Evaluation}

The replenisher in the flood rinse module needed to contain ammonium hydroxide and water in order to remove the etch residues. The Ultra Etch Aqueous replenisher that was being used contained water, ammonium hydroxide, and ammonium chloride. The ammonium chloride was added to help sustain the chloride level in the main etch sump. (The spent flood rinse chemistry emptied into the etch sump as new flood rinse chemistry entered the flood rinse modules.) While a higher concentration of ammonium hydroxide and ammonium chloride might be considered added insurance in removing etch residues, excessive alkalinity levels resulting from these chemistries degrade the aqueous processable dry film photoresists used in defining copper circuit patterns during the etch process.

Ultra Etch FL was considered to be the best candidate based on its similarities (except for pH and total alkalinity) to Ultra Etch Aqueous and the supplier's recommendation. A comparison from the Material Safety Data Sheets (MSDS) is shown in Table 1. 
Table 1. Comparison of Ultra Etch Aqueous, Ultra Etch FL, and Ultra Etch $\mathbf{5 0}$

\begin{tabular}{|l|c|c|c|}
\hline Properties & $\begin{array}{c}\text { Uitra Etch } \\
\text { Aqueous }\end{array}$ & Ultra Etch 50 & Ultra Etch FL \\
\hline Ammonium chloride $\left(\mathrm{NH}_{4} \mathrm{CL}\right)$ & $20-30 \%$ & $10-25 \%$ & $20-30 \%$ \\
\hline Ammonium hydroxide $\left(\mathrm{NH}_{4} \mathrm{OH}\right)$ & $<2 \%$ & $20-40 \%$ & $12-18 \%$ \\
\hline pH & $8.0-9.0$ & $8.2-8.8$ & 9.35 \\
\hline Specific gravity & 1.07 & 1.021 & 1.05 \\
\hline Total Alkalinity (Normality) & $0.1 \mathrm{~N}$ & $6.5 \mathrm{~N}$ & $3.5 \mathrm{~N}$ \\
\hline
\end{tabular}

The effect of Ultra Etch FL on the copper etching process was previously known from earlier studies; however, its effect on the photoresists being used for production, DuPont's 4615 and DuPont's 9015, was not known. MacDermid suggested that although excessive pH was detrimental to the aqueous processable photoresists in the etch module, the total alkalinity, more so than excessive $\mathrm{pH}$, of the flood rinse chemistry would be detrimental to the photoresist. MacDermid suggested modifications to the Ultra Etch chemistry and to the etch system that may provide acceptable results. These suggestions included

- adding deionized water to the flood rinse chemistry to lower the total alkalinity (and $\mathrm{pH}$ ),

- increasing the exhaust at the flood rinse module to reduce the $\mathrm{pH}$, and

- lowering the flow or completely shutting off the flood rinse in the last set of flood rinse tubes since that was the location where the incoming (high $\mathrm{pH}$ and alkalinity) replenisher was added.

\section{Experiment \#1 - Evaluating Worst Case Conditions of Ultra Etch FL}

To determine if Ultra Etch FL used under "worst-case" conditions would degrade the photoresists, fresh or "as-received" Ultra Etch FL was used in the flood rinse module, and the exhaust at the flood rinse module was shut off. Because thick copper requires a longer etch time-longer exposure of the photoresist to the etch and flood rinse modules-3-ounce copper clad laminate (laminate covered on each side with 3 ounces of copper per square foot) was used instead of the 0.5 -ounce or 1-ounce copper normally processed.

Standard 12" X 12" panels were used. DuPont's 4615 photoresist was laminated to 24 of the copper clad panels, and DuPont's 9015 photoresist was laminated to the remaining 24 copper clad panels. The panels were imaged with a special test pattern with a series of $0.005^{n}, 0.004^{\prime \prime}$, and $0.003^{n}$ path widths. (See Appendix A.)

Initially, 12 panels with each photoresist type were etched using fresh Ultra Etch Aqueous for a baseline comparison, and 12 with each photoresist type were to be etched using fresh Ultra Etch FL. An Atotech Sigma series etch system, made by The Chemcut Equipment Group, was used to etch panels during this experiment. 
Ultra Etch Aqueous was used in the flood rinse module first. At an estimated normal etch time for 3-ounce copper, 8 inches per minute conveyor speed (6.25 minutes), the 9015 photoresist was completely stripped during the etch process and about $50 \%$ of the 4615 photoresist was stripped. The etch time was excessive even for 3-ounce copper; therefore, the conveyor speed was increased to 15 inches per minute ( 3.33 minutes). Again, all of the 9015 photoresist was stripped. The 4615 photoresist patterns wider than $0.010^{\prime \prime}$ (border areas, phototool identification, etc.) remained. The etch time was reduced once more to 2.5 minutes (conveyor speed set at 20 inches per minute). Most of the 9015 photoresist was removed, but most of the 4615 photoresist patterns wider than $0.010^{\prime \prime}$ remained and $75 \%$ of the 4615 photoresist remained on the patterns less than $0.010^{\prime \prime}$ in width.

The remaining panels were etched at decreasing etch times to determine how much time each photoresist could take in the etch chamber before breaking down. At a conveyor speed of 25 inches per minute ( 2 minutes), all of the 4615 was acceptable and even some of the 9015 remained on the narrow patterns. Since the predominate copper thickness for FM\&T product was 1 ounce or less, one panel with 4615 and one panel with 9015 were etched at 35 inches per minute (1.43 minutes), the speed commonly used for etching 1-ounce copper. All of the 4615 photoresist was acceptable and about $85 \%$ of the 9015 photoresist was acceptable.

Based on the results of the Ultra Etch Aqueous and since the higher $\mathrm{pH}$ of the Ultra Etch FL was assumed to be more aggressive at degrading the photoresists, etching panels at the long etch time required for 3-ounce copper was not done. Instead, the first panels, etched using Ultra Etch FL in the flood rinse module, were etched at 35 inches per minute to determine if the fresh Ultra Etch FL could be considered as a replacement--even for etching 1-ounce copper. Most of the 4615 photoresist appeared to be acceptable; however, only $50 \%$ of the 9015 photoresist remained on the panels. There was no need to subject the photoresists to longer etch times.

From this evaluation it appeared that the baseline photoresists and Ultra Etch Aqueous in the flood rinse module were not acceptable for fine line etching of thick copper clad product. Fresh Ultra Etch FL was only slightly more aggressive in attacking photoresist than was the Ultra Etch Aqueous. Also, the 4615 photoresist was found to be more resistant to chemical attack than the 9015 .

\section{Experiment \#2 - Evaluating Best Case Conditions of Ultra Etch FL}

Modifications were made to the etch process as MacDermid recommended to determine if the Ultra Etch FL under ideal conditions would be acceptable. The exhaust near the flood rinse module was fully opened, the replenisher flow to the last set of spray tubes in the flood rinse module was shut off, and the replenisher was allowed to age for three days in the flood rinse module sump prior to the experiment, to allow the $\mathrm{pH}$ to drop.

Also, two etch systems were used to determine if the difference in etch equipment designs was significant. The older system, a Chemcut model 547, was compared to the newer system, an Atotech Sigma Series etch system, made by Chemcut Equipment Group.

Five $12^{\prime \prime} \times 12^{\prime \prime}$ panels with 2-ounce copper on each side were coated with 4615 photoresist and five more were coated with 9015 photoresist. A pattern with a broad range of path widths was used to image the photoresist. (See Appendix B.) Four of each were etched in the new etcher and one of each in the old etcher (which was using the baseline Ultra Etch Aqueous in the FRM). 
The tank analyses of the Chemcut and Atotech etchers prior to etching the panels are shown in Table 2.

Table 2. Chemical Analysis Prior to Etching Panels

\begin{tabular}{|c|c|c|c|}
\hline & $\begin{array}{c}\text { Copper } \\
\text { (gramsiliten) }\end{array}$ & $\begin{array}{c}\text { Chloride } \\
\text { (gramsilter) }\end{array}$ & pH \\
\hline OPERATING LIMITS & $145-165$ & $177-212$ & $7.6-7.8$ \\
\hline ATOTECH Sigma & 160.6 & 190.0 & 7.7 \\
\hline Chemcut 547 & 156.0 & 205.0 & 7.6 \\
\hline
\end{tabular}

The system operating parameters are shown in Table 3.

Table 3. Comparison of Chemcut and Atotech System Operating Parameters

\begin{tabular}{|l|c|c|}
\hline Parameter & Chemcuts.7 & Atotech Sigma \\
\hline $\begin{array}{l}\text { Conveyor speed } \\
\text { (inches/minute) }\end{array}$ & 25 & 20 \\
\hline $\begin{array}{l}\text { Etch time } \\
\text { (minutes) }\end{array}$ & 1.8 & 2.5 \\
\hline $\begin{array}{l}\text { Spray pressure } \\
\text { (psi) }\end{array}$ & $\begin{array}{l}10 \text { lower } \\
10 \text { upper }\end{array}$ & $\begin{array}{l}18 \text { lower } \\
20 \text { upper }\end{array}$ \\
\hline $\begin{array}{l}\text { Oscillation rate } \\
\text { (cycles/minute) }\end{array}$ & N/A & 30 \\
\hline
\end{tabular}

The panels etched on the Atotech etcher had photoresist paths lifted from all lines below 0.010 " in width; however, the panels etched on the Chemcut etcher had better results.

A sample of the Ultra Etch Aqueous from the old etcher's flood rinse module sump was found to have a $\mathrm{pH}$ of 8.4--higher than the $\mathrm{pH}$ of the replenisher in the new etcher's flood rinse module sump. These results indicated that a difference in etch system designs, such as the etchant spray mechanics or design of the flood rinse module or exhaust location, may be significant.

Table 4 lists the comparisons between the old and new etch system's nozzle configuration. The nozzle flow rate, spray shape, and distance to the workpiece were the same for both systems. The nozzle density (quantity per square feet of chamber space) was known to be different, but the difference was thought to be insignificant. The lower spray pressure and higher nozzle density of the old system may have been the contributor.

Table 4. Comparison of Chemcut and Atotech System Nozzle Configuration

\begin{tabular}{|l|c|c|}
\hline Spray area & Ghemout 549 & Alotech Sigma \\
& $9.375 \mathrm{ft}^{\prime \prime}$ & $12.5 \mathrm{ft}^{2}$ \\
$\left(45^{\prime \prime}\right.$ long $\times 30^{\prime \prime}$ wide $)$ & $\left(50^{\prime \prime}\right.$ long $\times 30^{\prime \prime}$ wide $)$ \\
\hline Spray tubes, upper & 7 & 6 \\
\hline Spray tubes, lower & 7 & 6 \\
\hline Nozzle type & Solid cone & Solid cone \\
\hline Nozzles per tube & 8 & 7 \\
\hline Nozzles/ft" & 6.0 & 3.4 \\
\hline Nozzle flow rating @ 40 psi & 1.5 & 1.5 \\
\hline
\end{tabular}


When undiluted Ultra Etch FL was evaluated as a replacement replenisher for Ultra Etch Aqueous, the aqueous processable photoresist was attacked. However, the attack was not as severe in one etch system (Chemcut 547) as it was in the other etch system (Atotech Sigma Series).

Because the photoresists were attacked in both systems, a third experiment was designed which included adjustments to the Ultra Etch FL chemistry.

\section{Experiment \#3 - Modification to the Ultra Etch FL Chemistry}

Standard 12" X 12" panels were used. Panels were processed as shown in Appendix C. Some panels had 1-ounce copper on each side and some had 2-ounce copper on each side.

DuPont's 4615 and 9015 dry film photoresists were used. Some of the panels were imaged with a special test pattern with a variety of line and space widths as well as other features (see Appendix B, Tool-Made Sample Artwork), and some were imaged with a special test pattern used for conductor analysis testing (see Appendix D, Conductor Analysis Test Pattern). Panel numbering sequence is shown in Appendix $E$. Panels were etched using the Chemcut Model 547 spray etching system.

The etch bath or "Chem 3 " bath requirements for production etching were

$\begin{array}{ll}\text { Copper content } & 145-165 \text { grams/liter } \\ \text { Chloride content } & 177-212 \text { grams/liter } \\ \text { pH } & 7.6-7.8\end{array}$

The chemical analysis of the Ultra Etch FL and the three adjustments that were used are shown in Table 5.

Table 5. Chemical Analysis of the Ultra Etch FL and Ultra Etch Variations

\begin{tabular}{|c|c|c|c|c|}
\hline Chemistris & Nor & Brorite & pit & Tolathalinity \\
\hline FL As Received & $4.36 \mathrm{M}$ & 154.8 grams/liter & 9.7 & $3.4 \mathrm{~N}$ \\
\hline FL, Dilute 50\% & $1.96 \mathrm{M}$ & 69.7 grams/liter & 9.6 & $1.4 \mathrm{~N}$ \\
\hline FL, Dilute $25 \%$ & $0.83 M$ & 29.6 grams/liter & 9.4 & $0.5 \mathrm{~N}$ \\
\hline FL, Dilute 5\% & $0.17 \mathrm{M}$ & 5.9 grams/liter & 9.4 & $0.05 \mathrm{~N}$ \\
\hline
\end{tabular}

The "as-received" Ultra Etch FL was used in the flood rinse module first. The known analysis of the etch bath and flood rinse module chemistry at the close of the previous day are shown in Table 6. The $\mathrm{pH}$ was found to be low so ammonium hydroxide was added to the etch sump in order to bring the $\mathrm{pH}$ up. A second $\mathrm{pH}$ measurement of $\mathrm{Chem} 3$ verified that the $\mathrm{pH}$ was within production operating limits. 
On the day of the experiment, a sample of the etch bath was removed prior to etching but the analysis was done several hours later and was not known prior to etching. The results that came from the laboratory from this sample are also shown in Table 6.

Table 6. $100 \%$ Ultra Etch FL and Chem 3 Analysis

\begin{tabular}{|l|c|c|c|c|}
\hline & $\begin{array}{c}\text { Copper } \\
\text { (cramsititer) }\end{array}$ & $\begin{array}{c}\text { Chloride } \\
\text { (grams/liter) }\end{array}$ & pH & Total Alkalinity \\
\hline Chem 3 (previous day) & 150.5 & 210.4 & 7.3 & - \\
\hline Chem 3 pH after adjusting & & & 7.7 & \\
\hline FL from barrel & & 154.8 & 9.7 & $3.4 \mathrm{~N}$ \\
\hline Chem 3 (beginning of evaluation) & 127.6 & 200.9 & ${ }^{*} 8.2$ & \\
\hline
\end{tabular}

"pH was over the upper limits.

Two panels with 2-ounce/2-ounce copper, one with the 9015 photoresist and one with the 4615 photoresist patterned with the tool-made sample pattern, were etched. When the panels came out of the dryer, both photoresists were completely stripped off. Even though the photoresists were stripped, the copper patterns (except for those with conductor widths less than 0.010 " and space widths less than 0.005", Coupon C, Area 8) were in tact and the surface of the conductors was flat and shiny in appearance, indicating that the photoresist had been damaged late in the etch module or in the flood rinse module. Had the photoresist been damaged early in the etch module, the copper surface of the 0.010 " wide lines would have been slightly etched, having a matte appearance.

This was repeated once again and the same results were observed.

During normal production etching with the Ultra Etch Aqueous replenisher in the flood rinse modules, it is not uncommon to have photoresist failure on narrow features (below $0.005^{\text {" in }}$ width). The etch process at FM\&T/KC was never required to perform and therefore never characterized for features smaller than these.

Suspecting the alkalinity of the full strength Ultra Etch FL to be a major contributor to the photoresist degradation, the full strength Uitra Etch FL was removed from the flood rinse modules and replaced with a mixture of $50 \%$ Ultra Etch FL and $50 \%$ deionized (DI) water. The analysis of this chemistry and Chem 3 prior to further etching is shown in Table 7.

Table 7. 50\% Ultra Etch FL and Chem 3 Analysis

\begin{tabular}{|c|c|c|c|c|}
\hline 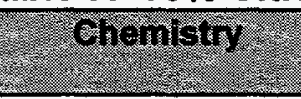 & 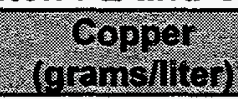 & 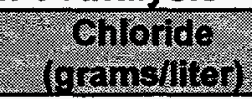 & $\mathrm{pr}$ & Protalingling \\
\hline Chem 3 & 126.4 & 203.3 & 8.2 & \\
\hline $50 \%$ Ultra Etch FL & & 69.7 & 9.6 & 1.4 \\
\hline FRM 1 & 2.5 & 153.7 & 9.4 & \\
\hline FRM 2 & 6.4 & 152.5 & 9.4 & \\
\hline
\end{tabular}

Two of the 2-ounce/2-ounce copper clad panels with 4615 photoresist and two with the 9015 photoresist, patterned with the tool-made sample pattern, were etched. 
There was some attack on the 4615 photoresist. The photoresist was stripped from areas with feature widths less than 0.005 ", loosened in some areas, and adhered in other areas. Copper features $0.010^{\prime \prime}$ and wider were acceptable.

All of the 9015 photoresist was stripped off during the etch operation, but again copper features $0.010^{\prime \prime}$ and wider were acceptable.

In order to determine if the flood rinse chemistry was contributing to the degradation of the photoresist, the flood rinse was shut off and two more panels (one with 9015 photoresist and one with 4615 photoresist) were etched.

The $\mathbf{4 6 1 5}$ photoresist was loose in some places but only in those areas with feature widths less than $0.005^{\prime \prime}$ wide. The 9015 photoresist was loose but not completely removed.

At this time, the laboratory analysis was received from the sample removed at the beginning of the day. (See Table 6.) Because the pH in the etch bath was excessive (8.2) and the copper content low, the etch bath was adjusted by etching 90 ounces of copper in the etch bath. A sample of Chem 3 after the copper addition was analyzed and found to be 7.9.

With the flood rinse still shut off, one of the 2-ounce/2-ounce copper clad panels with 4615 photoresist and one with the 9015 photoresist, patterned with the tool-made sample pattern, were etched with the $7.9 \mathrm{pH}$ etch chemistry. No difference was noticed on the panels with 4615 photoresist that were etched with the $8.2 \mathrm{pH}$ chemistry.

The 9015 photoresist, however, looked much better after lowering the $\mathrm{pH}$ of the etch bath. Photoresist was still attached to the 0.010 " wide lines.

With the etch bath now in operating limits, the flood rinse module was turned on to evaluate the effects of the flood rinse. Again, one of the 2-ounce/2-ounce copper clad panels with 4615 photoresist and one with the 9015 photoresist, patterned with the tool-made sample pattern, were etched. The 9015 photoresist was completely stripped and most of the 4615 photoresist was attacked and loosened. This was an indication that the $50 \%$ Uitra Etch FL was still too aggressive on the photoresist. The flood rinse was shut off and two more panels were etched to verify that the flood rinse chemistry was indeed the contributor to photoresist failure. Both the 4615 and 9015 photoresists were acceptable after etching.

The $50 \%$ Ultra Etch was removed from the flood rinse modules and replaced with a solution of $25 \%$ Ultra Etch FL. The analysis of the various chemistries is shown in Table 8.

Table 8. 25\% Ultra Etch FL and Chem 3 Analysis

\begin{tabular}{|l|c|c|c|c|}
\hline \multirow{2}{*}{ Chemisty) } & $\begin{array}{c}\text { Copper } \\
\text { (oraminter) }\end{array}$ & $\begin{array}{c}\text { Chloride } \\
\text { (gramsilte) }\end{array}$ & $\mathrm{pH}$ & Total Alkalinity \\
\hline Chem 3 & 127.0 & 195.0 & 7.8 & \\
\hline $25 \%$ Ultra Etch FL & & 29.6 & 9.41 & 0.5 \\
\hline
\end{tabular}


One 2-ounce/2-ounce copper panel with 4615 photoresist and one with 9015 photoresist, patterned with the tool-made sample pattern, were etched. Both photoresists appeared to be more degraded than with the normal production etch process. The total alkalinity ( 0.5 normal) of the flood rinse module was still higher than the production replenisher, Ultra Etch Aqueous, with a total alkalinity of 0.1 .

Two 1-ounce/1-ounce copper clad panels with 9015 photoresist, patterned with the conductor analysis test pattern (Appendix D), were etched.

The photoresist on the top of the panels was completely stripped off. The photoresist on the bottom of the panels was loose but still in place. The effects of etchant puddling on the top side of the panels was most likely the contributor to the premature photoresist failure.

The $25 \%$ solution of Ultra Etch FL was removed from the flood rinse modules, and the Ultra Etch was diluted down to $5 \%$. The analysis of the barrel and the analysis of the other chemistries are shown in Table 9.

Table 9. 5\% Ultra Etch FL, Chem 3, and FRM Analysis

\begin{tabular}{|l|c|c|c|c|}
\hline Chemistry & $\begin{array}{c}\text { Copper } \\
\text { (grams/iter) }\end{array}$ & $\begin{array}{c}\text { Chloride } \\
\text { (gramsliter) }\end{array}$ & pH & Total Alkalinity \\
\hline Chem 3 & 125.1 & 191.5 & 7.6 & \\
\hline $5 \%$ Ultra Etch FL & & 5.9 & 9.4 & 0.05 \\
\hline FRM \#1 (5\% FL) & 2.5 & 35.5 & 8.6 & \\
\hline FRM \#2 (5\% FL) & 24.1 & 67.4 & 8.5 & \\
\hline
\end{tabular}

During this run, both replenisher pumps were continually running. One pumped fresh Ultra Etch 50 directly into Chem 3 (to maintain $\mathrm{pH}$, copper concentration, and chloride concentration), and the other pumped fresh 5\% Ultra Etch FL into flood rinse modules 1 and 2.

One 2-ounce/2-ounce copper clad panel with 4615 photoresist and one with 9015 photoresist, patterned with the tool-made sample pattern, were etched. Both were acceptable, being typical of normal production.

Fourteen 1-ounce/1-ounce copper clad panels with 9015 photoresist and patterned with the CAT Pattern were etched. All of the panels looked similar. Four were run at a speed of 53 inches per minute, two were run at 55 , seven were run at 60 , and one panel was run at 65 inches per minute.

Panels 113,114 , and 115, which were etched at a speed of 53 inches per minute, and panels $104,106,109,110,111$, and 112, which were etched at a speed of 60 inches per minute, were tested electrically using the conductor analysis tester. Panel marking is shown in Appendix $E$. The results summarized in Tables 10 and 11 and are detailed in Appendix F. 
Table 10. Electrical Test Data of Panels Etched at a Speed of 53 Inches Per Minute (Panels \#113, 114, 115) [Tested 300 modules (areas) for each feature]

\begin{tabular}{|c|c|c|c|}
\hline $\begin{array}{l}\text { EENTURE } \\
\text { AND SIZE }\end{array}$ & $\begin{array}{l}\text { DEFET } \\
\text { COUNT }\end{array}$ & FEATURE & 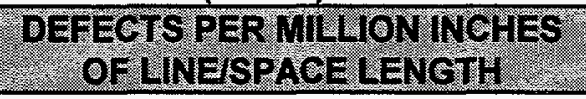 \\
\hline \multicolumn{4}{|c|}{ TOP SIDE OF PANEL } \\
\hline $0.005^{\prime \prime}$ line & 32 & $89.33 \%$ & 8051 \\
\hline $0.005^{\prime \prime}$ space & 0 & $100.00 \%$ & 0 \\
\hline $0.006^{n}$ line & 23 & $92.33 \%$ & 5750 \\
\hline $0.006^{\prime}$ space & 0 & $100.00 \%$ & 0 \\
\hline $0.007^{n}$ line & 13 & $95.67 \%$ & 3222 \\
\hline $0.007^{n}$ space & 0 & $100.00 \%$ & 0 \\
\hline $0.008^{\prime \prime}$ line & 10 & $96.67 \%$ & 2485 \\
\hline \multicolumn{4}{|c|}{ BOTTOM SIDE OF PANEL } \\
\hline $0.005^{\prime \prime}$ line & 1 & $99.67 \%$ & 238 \\
\hline $0.005^{\prime \prime}$ space & 0 & $100.00 \%$ & 0 \\
\hline $0.006^{\prime \prime}$ line & 1 & $99.67 \%$ & 241 \\
\hline $0.006^{\prime \prime}$ space & 1 & $99.67 \% \%$ & 245 \\
\hline $0.007^{\prime \prime}$ line & 0 & $100.00 \%$ & 0 \\
\hline $0.007^{\prime \prime}$ space & 0 & $100.00 \%$ & 0 \\
\hline $0.008^{\prime \prime}$ line & 0 & $100.00 \%$ & 0 \\
\hline
\end{tabular}

Table 11. Electrical Test Data of Panels Etched at a Speed of 60 Inches Per Minute (Panels \#104, 106, 109, 110, 111, 112) [Tested 300 modules (areas) for each feature]

\begin{tabular}{|c|c|c|c|}
\hline 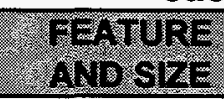 & $\begin{array}{l}\text { DEEECT } \\
\text { COUNR }\end{array}$ & $\begin{array}{l}\text { FeATRE } \\
\text { MELS }\end{array}$ & 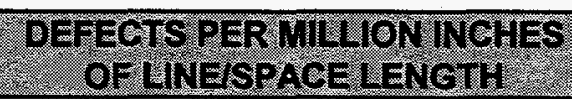 \\
\hline \multicolumn{4}{|c|}{ TOP SIDE OF PANEL } \\
\hline $0.005^{\prime \prime}$ line & 36 & $94 \%$ & 4417 \\
\hline $0.005^{\prime \prime}$ space & 2 & $99.67 \%$ & 243 \\
\hline $0.006^{\prime \prime}$ line & 17 & $97.17 \%$ & 2072 \\
\hline $0.006^{\prime \prime}$ space & 2 & $99.67 \%$ & 245 \\
\hline $0.007^{\prime \prime}$ line & 18 & $97.00 \%$ & 2216 \\
\hline $0.007^{\prime \prime}$ space & 1 & $99.83 \%$ & 124 \\
\hline $0.008^{\prime \prime}$ line & 13 & $97.83 \%$ & 1607 \\
\hline \multicolumn{4}{|c|}{ BOTTOM SIDE OF PANEL } \\
\hline $0.005^{\prime \prime}$ line & 6 & $99.00 \%$ & 717 \\
\hline $0.005^{\prime \prime}$ space & 33 & $94.50 \%$ & 4117 \\
\hline $0.006^{\prime \prime}$ line & 2 & $99.67 \%$ & 241 \\
\hline $0.006^{\prime \prime}$ space & 19 & $96.83 \%$ & 2364 \\
\hline $0.007^{n}$ line & 1 & $99.83 \%$ & 121 \\
\hline $0.007^{n}$ space & $\overline{18}$ & $97.00 \%$ & 2258 \\
\hline $0.008^{\prime \prime}$ line & 1 & $99.83 \%$ & 122 \\
\hline
\end{tabular}


The data listed represents line and space yields. A line defect is detected when there is a break or "open circuit" in a line. A space defect is detected when a shor is detected between the lines on either side of the space. The line yields were slightly better at a conveyor speed of 60 inches per minute, but the space yields were better at a conveyor speed of 53 inches per minute. At the slower speed of 53, the conveyor is allowing additional copper to be removed from the spaces between the conductors. At a faster speed of 60, the panels are not etched as long and conductor widths are slightly wider. Any place along the conductor that is marginal enough to pass at 60 inches per minute would have been a defect at a longer etch time (slower conveyor speed).

At the end of the day, chemical analyses were taken. Those results are shown in Table 12.

Table 12. 5\% Ultra Etch FL, Chem 3, and FRM Final Analysis

\begin{tabular}{|c|c|c|c|c|}
\hline s. & (apuper & 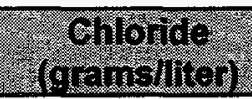 & 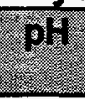 & 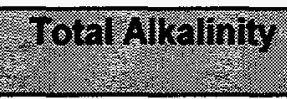 \\
\hline Chem 3 & 118.7 & 177.3 & 7.6 & \\
\hline $5 \%$ Ultra Etch FL & & 5.9 & 9.4 & 0.05 \\
\hline FRM \#1 (5\% FL) & 1.9 & 11.8 & 9.3 & \\
\hline FRM \#2 (5\% FL) & 11.4 & 23.6 & 9.4 & \\
\hline
\end{tabular}

During this evaluation no ammonium chloride was added to the modified Ultra Etch FL. Although this chemistry, without the ammonium chloride, was adequate for rinsing off etch residues, with continued use, the chloride level in the etch bath would have dropped due to the addition of the low-chloride flood rinse chemistry.

The amount of ammonium chloride that would have been needed to raise the chloride level in solution to operating limits was calculated and added to the solution. The subsequent analysis showed that the chloride level did increase and that it increased to the desired value.

Some panels were etched with this chemistry and were found to be acceptable.

\section{Accomplishments}

Ultra Etch FL, by itself, attacked the two photoresists used during the evaluation (DuPont's 9015 and $4615 \mathrm{dry}$ film). As the Ultra Etch FL was diluted with water to decrease the total alkalinity, the photoresist attack was decreased. Modified Uitra Etch FL was an effective flood rinse chemistry provided the total alkalinity was below 0.1 normal. Adding water and ammonium chloride to Ultra Etch FL provided acceptable results in the flood rinse function and prevented damage to the aqueous processable photoresists.

In December 1996, this information was presented to a Qualification Evaluation Team made up of FM\&T and customer (Sandia National Laboratory) associates in Livermore, California. The Qualification Evaluation Team approved the modified Ultra Etch FL as a replacement for Ultra Etch Aqueous. 


\section{Appendix A}

Conductor Analysis Test Artwork 


\section{Conductor Analysis Artwork}

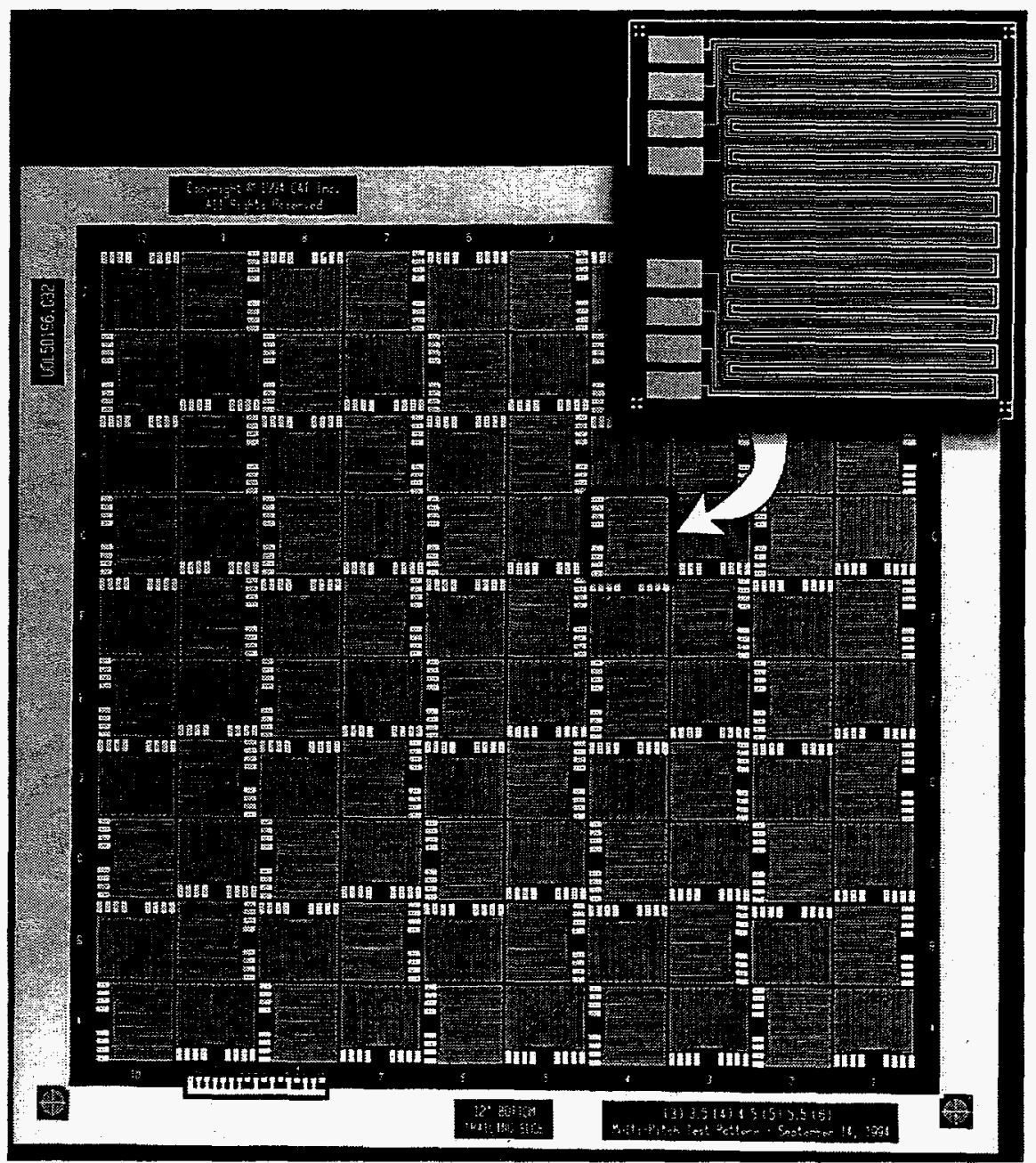

From CAT, Inc. ${ }^{1}$, used by permission.

${ }^{1}$ CAT, Inc., Conductor Analysis Technologies, Inc., Albuquerque, New Mexico 


\section{Appendix B}

Tool-Made Sample Artwork 
Tool Made Sample Artwork

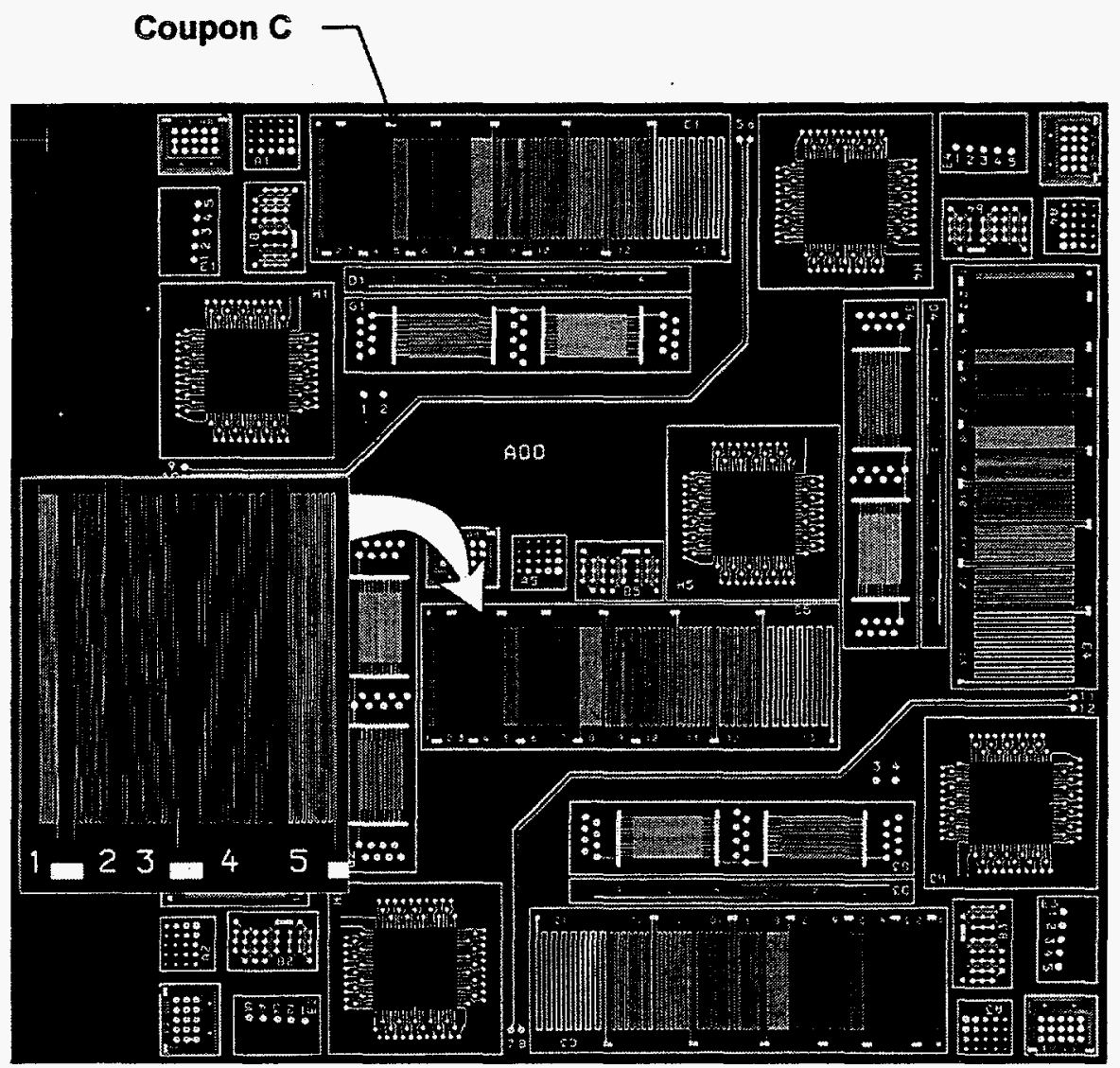

\begin{tabular}{|l|c|c|c|c|c|c|c|c|c|c|}
\hline Coupon C, Area & $\mathbf{1}$ & $\mathbf{2}$ & $\mathbf{3}$ & $\mathbf{4}$ & $\mathbf{5}$ & $\mathbf{6}$ & $\mathbf{7}$ & $\mathbf{8}$ & $\mathbf{9}$ & $\mathbf{1 0}$ \\
\hline Line width (mil) & 2 & 2 & 2 & 2 & 5 & 5 & 5 & 10 & 10 & 10 \\
Space width (mil) & 2 & 5 & 10 & 15 & 5 & $1-$ & 15 & 5 & 10 & 15 \\
\hline
\end{tabular}




\section{Appendix C}

\section{Test Panel Processing Sequence}


Test Panel Processing Sequence

\begin{tabular}{|c|c|c|}
\hline \multicolumn{3}{|c|}{ CHEMICAL CLEAN } \\
\hline Metex P507 & Concentration & 17.3 \\
\hline 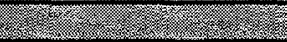 & Conveyor Speed & 38 inchesminute \\
\hline 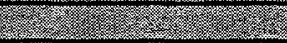 & Mefor Temperature & 142695 \\
\hline 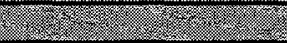 & Pressure, upaer & $208031 \%$ \\
\hline $27=3$ & Fressure lower & $19 \mathrm{psi}$ \\
\hline Water rinse & Pressure, upper & $19 \mathrm{psi}$ \\
\hline & Pressure, lower & $13 \mathrm{psi}$ \\
\hline sodrin & Temperature & $75.5 \%$ \\
\hline nersulfites: & Conveyor Speed & 80 inchesiminute. \\
\hline stifuricacte & Copper concentration & 10.5 gramsinter \\
\hline microetch & Sodium sersulate cone & 106 gramsnifer \\
\hline 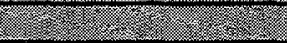 & Rressure, upger & $29 \mathrm{pst}$ \\
\hline$\sqrt[3]{12010}$ & Riessure, lower & 27 gis: \\
\hline Water rinse & Pressure, upper & $16 \mathrm{psi}$ \\
\hline & Pressure, lower & $19 \mathrm{psi}$ \\
\hline Maruatm dis? & $6 \ln ^{2}$ & \\
\hline
\end{tabular}

\section{PHOTORESIST LAMINATION}

\begin{tabular}{|l|l|l|}
\hline DuPont's 4615 & Roll temperature & $100^{\circ} \mathrm{C}$ \\
\hline & Board exit temp & $125 / 127^{\circ} \mathrm{F}$ \\
\hline & Speed & 0.5 meters $/ \mathrm{min}$. \\
\hline DuPont's 9015 & Roll temperature & $105^{\circ} \mathrm{C}$ \\
\hline & Board exit temp & $121^{\circ} \mathrm{F}$ \\
\hline & Speed & 0.5 meters $/ \mathrm{min}$. \\
\hline
\end{tabular}

EXPOSURE

\begin{tabular}{|l|l|l|}
\hline DuPont's 4615 & Step, (Stouffer 21) & 9 \\
\hline & Setting & 90 \\
\hline & Time & 16.8 seconds \\
\hline DuPont's 9015 & Step, (Stouffer 21) & 9 \\
\hline & Setting & 110 \\
\hline & Time & 20 seconds \\
\hline
\end{tabular}

DEVELOP

\begin{tabular}{|l|l|l|}
\hline & Solution temp & $84^{\circ} \mathrm{F}$ \\
\hline & $\mathrm{pH}$ & 11.1 \\
\hline & Sodium carbonate conc. & $1 \%$ \\
\hline DuPont's 4615 & Conveyor speed & 2.25 feet/minute \\
\hline DuPont's 9015 & Conveyor speed & 2 feet/minute \\
\hline
\end{tabular}

ETCH

\begin{tabular}{|lll|}
\hline & Temperature & $@ 126^{\circ} \mathrm{F}$ \\
\hline & Upper spray pressure & $26 \mathrm{psi}$ \\
\hline & Lower spray pressure & $12 \mathrm{psi}$ \\
\hline 1 oz/1 oz $\mathrm{Cu}$. & Conveyor speed & $53-65 \mathrm{in} / \mathrm{min}$. \\
\hline & Etch time & $51-41 \mathrm{~seconds}$ \\
\hline 2 oz/2 oz Cu & Conveyor speed & $26 \mathrm{in} / \mathrm{min}$. \\
\hline & Etch time & $104 \mathrm{~seconds}$ \\
\hline
\end{tabular}

*Upper spray pressure gauge was not working properly. The pressure was most likely around 15 psi based on the regular setting of the valve. 
Appendix D

Conductor Analysis Test Artwork 5 to 8 Mil Lines 
Conductor Analysis Test Artwork 5 to 8 Mil Lines

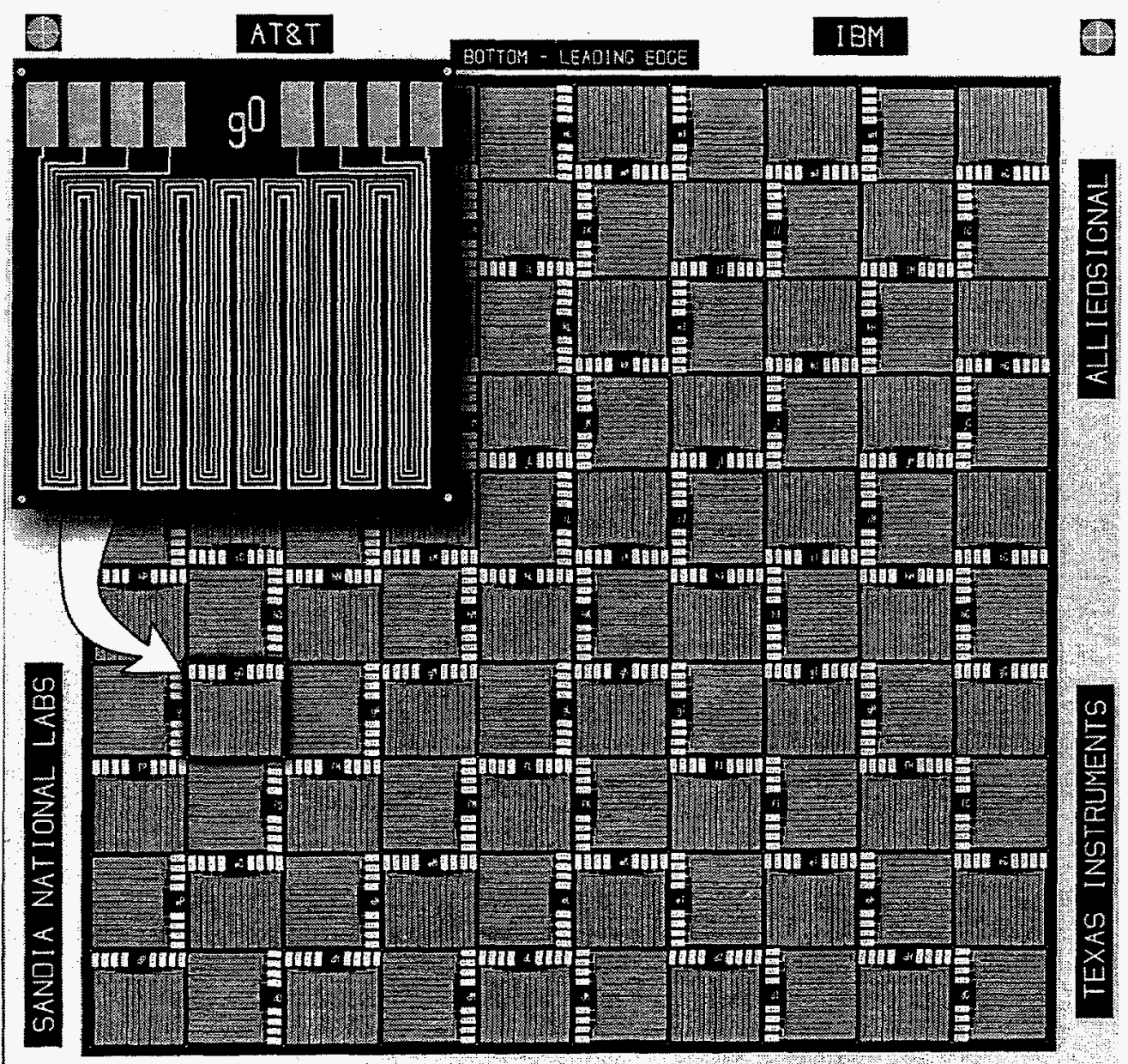

NCMS IMAGINC TEAM 5 TO 8-MIL UNIFORMITY TEST PATTERN: JAN 12, 1994) 
Appendix E

Panel Numbering and Description 


\section{Panel Numbering and Description}

Panels 90-1 - 90-6

9015 photoresist, 2-ounce/2-ounce copper TMS Artwork

Panels 46-1 - 46-6 4615 photoresist, 2-ounce/2-ounce copper TMS Artwork

Panels $101-116$ 9015 photoresist, 1-ounce/1-ounce copper, CAT Artwork

Panels 201 - 208 4615 photoresist, 2-ounce/2-ounce copper TMS Artwork Panels 209 - 216 9015 photoresist, 2-ounce/2-ounce copper TMS Artwork 
Appendix F

Conductor Analysis Electrical Test Results 
Feature Yield \& Defect Density Results

(From CAT, Inc. ${ }^{2}$, used by permission.)

Data Not Censored

All 100 Modules

Top Side of Panels

\begin{tabular}{|c|c|c|c|c|c|c|c|c|}
\hline $\begin{array}{c}\text { Artwork } \\
\text { Feature } \\
\text { Size } \\
\text { (mils) }\end{array}$ & $\begin{array}{c}\text { Target } \\
\text { Feature } \\
\text { Slze } \\
\text { (mils) }\end{array}$ & $\begin{array}{c}\text { Feature } \\
\text { Type }\end{array}$ & $\begin{array}{c}\text { Feature } \\
\text { Count }\end{array}$ & $\begin{array}{c}\text { Defect } \\
\text { Type }\end{array}$ & $\begin{array}{c}\text { Defect } \\
\text { Count }\end{array}$ & $\begin{array}{c}\text { Number } \\
\text { Good }\end{array}$ & $\begin{array}{c}\text { Feature } \\
\text { Yield } \\
\text { (\%) }\end{array}$ & $\begin{array}{c}\text { Defects } \\
\text { per } \\
\text { Million } \\
\text { Inches }\end{array}$ \\
\hline 5.00 & 4.00 & Line & 300 & Open & 32 & 268 & 89.33 & 8051 \\
\hline 5.00 & 6.00 & Space & 300 & Short & 0 & 300 & 100.00 & 0 \\
\hline 6.00 & 5.00 & Line & 300 & Open & 23 & 277 & 92.33 & 5750 \\
\hline 6.00 & 7.00 & Space & 300 & Short & 0 & 300 & 100.00 & 0 \\
\hline 7.00 & 6.00 & Line & 300 & Open & 13 & 287 & 95.67 & 3222 \\
\hline 7.00 & 8.00 & Space & 300 & Short & 0 & 300 & 100.00 & 0 \\
\hline 8.00 & 7.00 & Line & 300 & Open & 10 & 290 & 96.67 & 2486 \\
\hline
\end{tabular}

Bottom Side of Panels

\begin{tabular}{|c|c|c|c|c|c|c|c|c|}
\hline $\begin{array}{c}\text { Artwork } \\
\text { Feature } \\
\text { Size } \\
\text { (mils) }\end{array}$ & $\begin{array}{c}\text { Target } \\
\text { Feature } \\
\text { Size } \\
\text { (mils) }\end{array}$ & $\begin{array}{c}\text { Feature } \\
\text { Type }\end{array}$ & $\begin{array}{c}\text { Feature } \\
\text { Count }\end{array}$ & $\begin{array}{c}\text { Defect } \\
\text { Type }\end{array}$ & $\begin{array}{c}\text { Defect } \\
\text { Count }\end{array}$ & $\begin{array}{c}\text { Number } \\
\text { Good }\end{array}$ & $\begin{array}{c}\text { Feature } \\
\text { Yield } \\
(\%)\end{array}$ & $\begin{array}{c}\text { Defects } \\
\text { per } \\
\text { Million } \\
\text { Inches }\end{array}$ \\
\hline \hline 5.00 & 4.00 & Line & 300 & Open & 1 & 299 & 99.67 & 238 \\
\hline 5.00 & 6.00 & Space & 300 & Short & 0 & 300 & 100.00 & 0 \\
\hline 6.00 & 5.00 & Line & 300 & Open & 1 & 299 & 99.67 & 241 \\
\hline 6.00 & 7.00 & Space & 300 & Short & 1 & 299 & 99.67 & 245 \\
\hline 7.00 & 6.00 & Line & 300 & Open & 0 & 300 & 100.00 & 0 \\
\hline 7.00 & 8.00 & Space & 300 & Short & 0 & 300 & 100.00 & 0 \\
\hline 8.00 & 7.00 & Line & 300 & Open & 0 & 300 & 100.00 & 0 \\
\hline
\end{tabular}

Top \& Bottom Sides Combined

\begin{tabular}{|c|c|c|c|c|c|c|c|c|}
\hline $\begin{array}{c}\text { Artwork } \\
\text { Feature } \\
\text { Size } \\
\text { (mils) }\end{array}$ & $\begin{array}{c}\text { Target } \\
\text { Feature } \\
\text { Size } \\
\text { (mils) }\end{array}$ & $\begin{array}{c}\text { Feature } \\
\text { Type }\end{array}$ & $\begin{array}{c}\text { Feature } \\
\text { Count }\end{array}$ & $\begin{array}{c}\text { Defect } \\
\text { Type }\end{array}$ & $\begin{array}{c}\text { Defect } \\
\text { Count }\end{array}$ & $\begin{array}{c}\text { Number } \\
\text { Good }\end{array}$ & $\begin{array}{c}\text { Feature } \\
\text { Yield } \\
\text { (\%) }\end{array}$ & $\begin{array}{c}\text { Defects } \\
\text { per } \\
\text { Million } \\
\text { Inches }\end{array}$ \\
\hline \hline 5.00 & 4.00 & Line & 600 & Open & 33 & 567 & 94.50 & 4038 \\
\hline 5.00 & 6.00 & Space & 600 & Short & 0 & 600 & 100.00 & 0 \\
\hline 6.00 & 5.00 & Line & 600 & Open & 24 & 576 & 96.00 & 2943 \\
\hline 6.00 & 7.00 & Space & 600 & Short & 1 & 599 & 99.83 & 123 \\
\hline 7.00 & 6.00 & Line & 600 & Open & 13 & 587 & 97.83 & 1593 \\
\hline 7.00 & 8.00 & Space & 600 & Shon & 0 & 600 & 100.00 & 0 \\
\hline 8.00 & 7.00 & Line & 600 & Open & 10 & 590 & 98.33 & 1233 \\
\hline
\end{tabular}

AlliedSignal FMET

FL Etchant - Run 53

Pattem: Multi-pitch

CAP Version 1.01 - AlliedSignal KCD yield_c.tbl November 25, 1996

Design: [5] 5 [6] 6 [7] 7 [8]

November 25, 1996
Copyright $1995-1996$ CAT Inc.

All Rights Reserved

${ }^{2} \mathrm{CAT}$, Inc., Conductor Analysis Technologies, Inc., Albuquerque, New Mexico. 


\section{Conductor \& Space Yield by Panel}

(From CAT, inc. ${ }^{3}$, used by permission.)

Data Not Censored

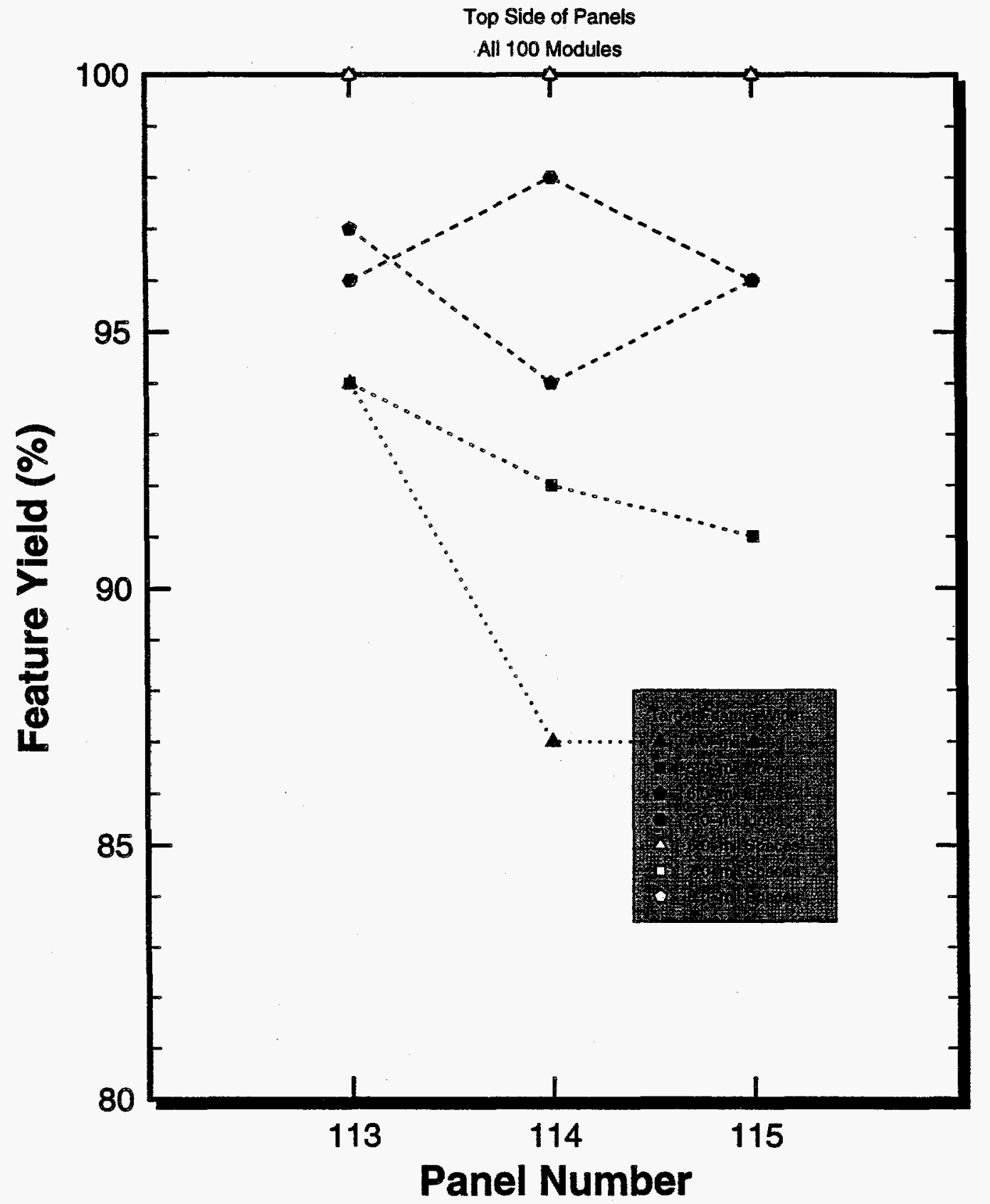

AlliedSignal FM\&T

FLEtchant-Run 53

CAP Version 1.01 - AlliedSignal KCD pyield_t.grf Pattem: Multi-pitch

Design: [5] 5 [6] 6 [7] 7 [8]

November 25,1996 Copyright 1 1995-1996 CAT inc. All Rights Reserved

${ }^{3}$ CAT, Inc., Conductor Analysis Technologies, Inc., Albuquerque, New Mexico. 


\section{Conductor \& Space Yield by Panel}

(From CAT, Inc. ${ }^{4}$, used by permission.)

Data Not Censored

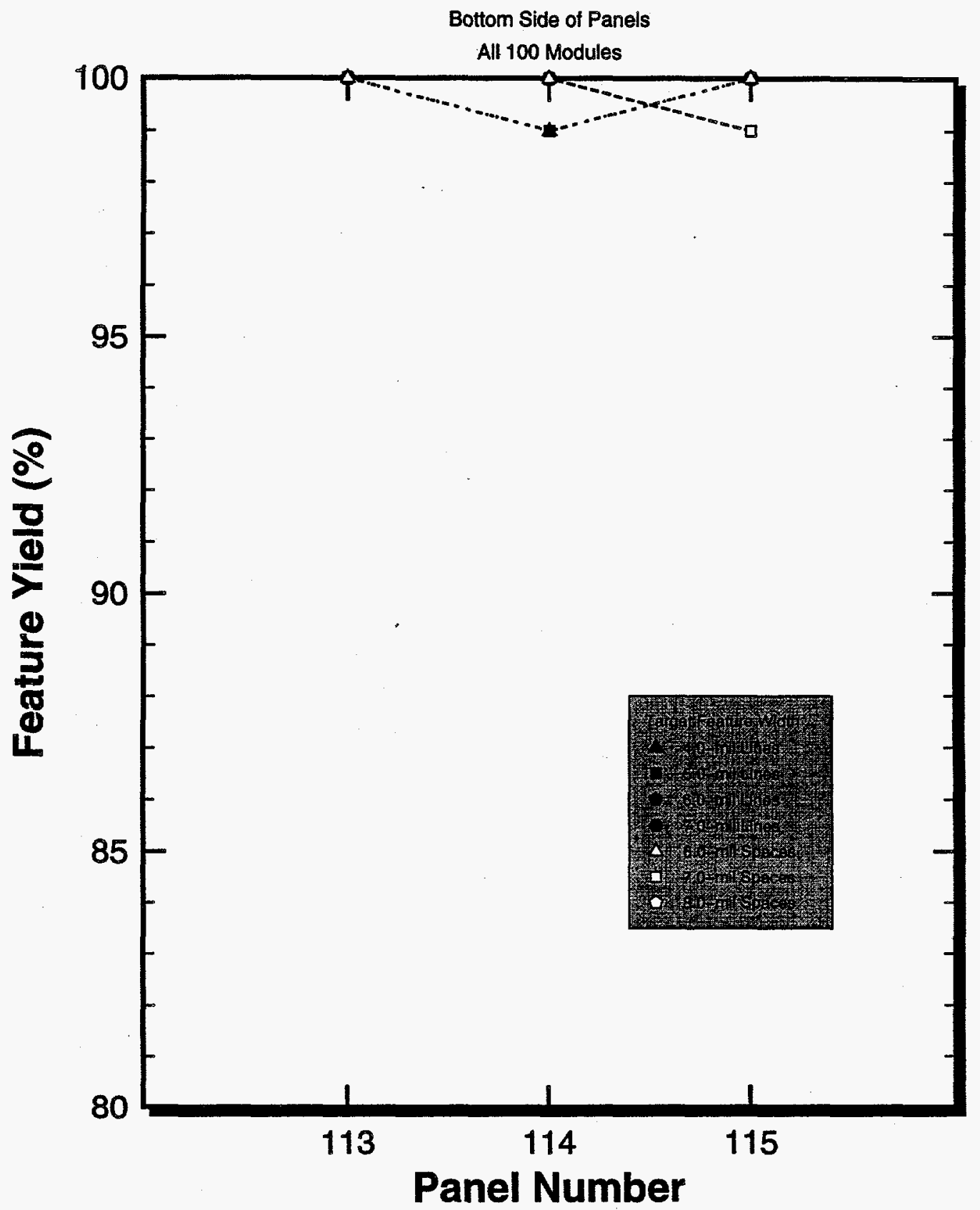

AlliodSignal FM\&T

CAP Version 1.01 - AlliedSignal KCD pyield_b.grt

FL Etchant - Run 53

Pattern: Multi-pitch

Novernber 25, 1996

Design: [5] 5 [6] 6 [7] 7 [8]

Copyright $\odot$ 1995-1996 CAT Inc.

All Rights Reserved

${ }^{4} \mathrm{CAT}$, Inc., Conductor Analysis Technologies, Inc., Albuquerque, New Mexico. 


\section{Conductor \& Space Yield by Panel}

(From CAT, Inc. ${ }^{5}$, used by permission.)

Data Not Censored

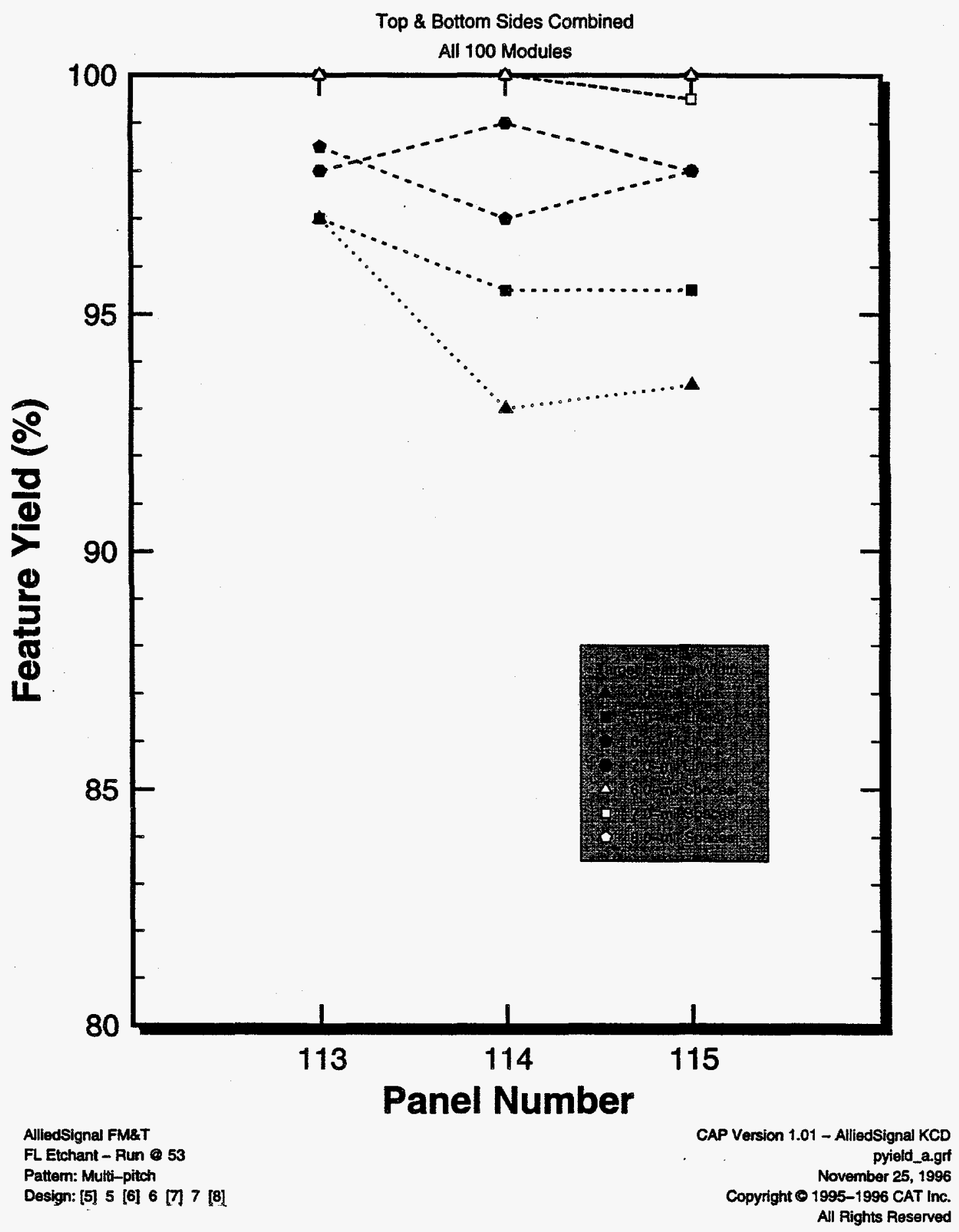

${ }^{5}$ CAT, Inc., Conductor Analysis Technologies, Inc., Albuquerque, New Mexico. 
Feature Yield \& Defect Density Results

(From CAT, Inc. ${ }^{6}$, used by permission.)

All 100 Modules

Top Side of Panels

\begin{tabular}{|c|c|c|c|c|c|c|c|c|}
\hline $\begin{array}{c}\text { Artwork } \\
\text { Feature } \\
\text { Size } \\
\text { (mils) }\end{array}$ & $\begin{array}{c}\text { Target } \\
\text { Feature } \\
\text { Size } \\
\text { (mils) }\end{array}$ & $\begin{array}{c}\text { Feature } \\
\text { Type }\end{array}$ & $\begin{array}{c}\text { Feature } \\
\text { Count }\end{array}$ & $\begin{array}{c}\text { Defect } \\
\text { Type }\end{array}$ & $\begin{array}{c}\text { Defect } \\
\text { Count }\end{array}$ & $\begin{array}{c}\text { Number } \\
\text { Good }\end{array}$ & $\begin{array}{c}\text { Feature } \\
\text { Yield } \\
(\%)\end{array}$ & $\begin{array}{c}\text { Defects } \\
\text { per } \\
\text { Million } \\
\text { Inches }\end{array}$ \\
\hline \hline 5.00 & 4.00 & Line & 600 & Open & 36 & 564 & 94.00 & 4417 \\
\hline 5.00 & 6.00 & Space & 600 & Short & 2 & 598 & 99.67 & 243 \\
\hline 6.00 & 5.00 & Line & 600 & Open & 17 & 583 & 97.17 & 2072 \\
\hline 6.00 & 7.00 & Space & 600 & Short & 2 & 598 & 99.67 & 245 \\
\hline 7.00 & 6.00 & Line & 600 & Open & 18 & 582 & 97.00 & 2216 \\
\hline 7.00 & 8.00 & Space & 600 & Short & 1 & 599 & 99.83 & 124 \\
\hline 8.00 & 7.00 & Line & 600 & Open & 13 & 587 & 97.83 & 1607 \\
\hline
\end{tabular}

\section{Bottom Side of Panels -}

\begin{tabular}{|c|c|c|c|c|c|c|c|c|}
\hline $\begin{array}{c}\text { Artwork } \\
\text { Feature } \\
\text { Size } \\
\text { (mils) }\end{array}$ & $\begin{array}{c}\text { Target } \\
\text { Feature } \\
\text { Size } \\
\text { (mils) }\end{array}$ & $\begin{array}{c}\text { Feature } \\
\text { Type }\end{array}$ & $\begin{array}{c}\text { Feature } \\
\text { Count }\end{array}$ & $\begin{array}{c}\text { Defect } \\
\text { Type }\end{array}$ & $\begin{array}{c}\text { Defect } \\
\text { Count }\end{array}$ & $\begin{array}{c}\text { Number } \\
\text { Good }\end{array}$ & $\begin{array}{c}\text { Feature } \\
\text { Yield } \\
(\%)\end{array}$ & $\begin{array}{c}\text { Defects } \\
\text { per } \\
\text { Million } \\
\text { Inches }\end{array}$ \\
\hline 5.00 & 4.00 & Line & 600 & Open & 6 & 594 & 99.00 & 717 \\
\hline 5.00 & 6.00 & Space & 600 & Short & 33 & 567 & 94.50 & 4117 \\
\hline 6.00 & 5.00 & Line & 600 & Open & 2 & 598 & 99.67 & 241 \\
\hline 6.00 & 7.00 & Space & 600 & Short & 19 & 581 & 96.83 & 2364 \\
\hline 7.00 & 6.00 & Line & 600 & Open & 1 & 599 & 99.83 & 121 \\
\hline 7.00 & 8.00 & Space & 600 & Short & 18 & 582 & 97.00 & 2258 \\
\hline 8.00 & 7.00 & Line & 600 & Open & 1 & 599 & 99.83 & 122 \\
\hline
\end{tabular}

Top \& Bottom Sides Combined

\begin{tabular}{|c|c|c|c|c|c|c|c|c|}
\hline $\begin{array}{c}\text { Artwork } \\
\text { Feature } \\
\text { Size } \\
\text { (mils) }\end{array}$ & $\begin{array}{c}\text { Target } \\
\text { Feature } \\
\text { Size } \\
\text { (mils) }\end{array}$ & $\begin{array}{c}\text { Feature } \\
\text { Type }\end{array}$ & $\begin{array}{c}\text { Feature } \\
\text { Count }\end{array}$ & $\begin{array}{c}\text { Defect } \\
\text { Type }\end{array}$ & $\begin{array}{c}\text { Defect } \\
\text { Count }\end{array}$ & $\begin{array}{c}\text { Number } \\
\text { Good }\end{array}$ & $\begin{array}{c}\text { Feature } \\
\text { Yield } \\
\text { (\%) }\end{array}$ & $\begin{array}{c}\text { Defects } \\
\text { per } \\
\text { Million } \\
\text { Inches }\end{array}$ \\
\hline 5.00 & 4.00 & Line & 1200 & Open & 42 & 1158 & 96.50 & 2543 \\
\hline 5.00 & 6.00 & Space & 1200 & Short & 35 & 1165 & 97.08 & 2154 \\
\hline 6.00 & 5.00 & Line & 1200 & Open & 19 & 1181 & 98.42 & 1150 \\
\hline 6.00 & 7.00 & Space & 1200 & Short & 21 & 1179 & 98.25 & 1297 \\
\hline 7.00 & 6.00 & Line & 1200 & Open & 19 & 1181 & 98.42 & 1161 \\
\hline 7.00 & 8.00 & Space & 1200 & Short & 19 & 1181 & 98.42 & 1183 \\
\hline 8.00 & 7.00 & Line & 1200 & Open & 14 & 1186 & 98.83 & 861 \\
\hline
\end{tabular}

AlliedSignal FM:T

FL Etchant - Run 60

Pattem: Multi-pitch

Design: [5] 5 [6] 6 [7] 7 [8]
CAP Version 1.01 - AlliedSignal KCD yield.tbl

November 25, 1996

Copyright $\odot 1995-1996$ CAT Inc. All Rights Reserved

${ }^{6}$ CAT, Inc., Conductor Analysis Technologies, Inc., Albuquerque, New Mexico. 
Conductor \& Space Yield by Panel

(From CAT, Inc. ', used by permission.)

Data Not Censored

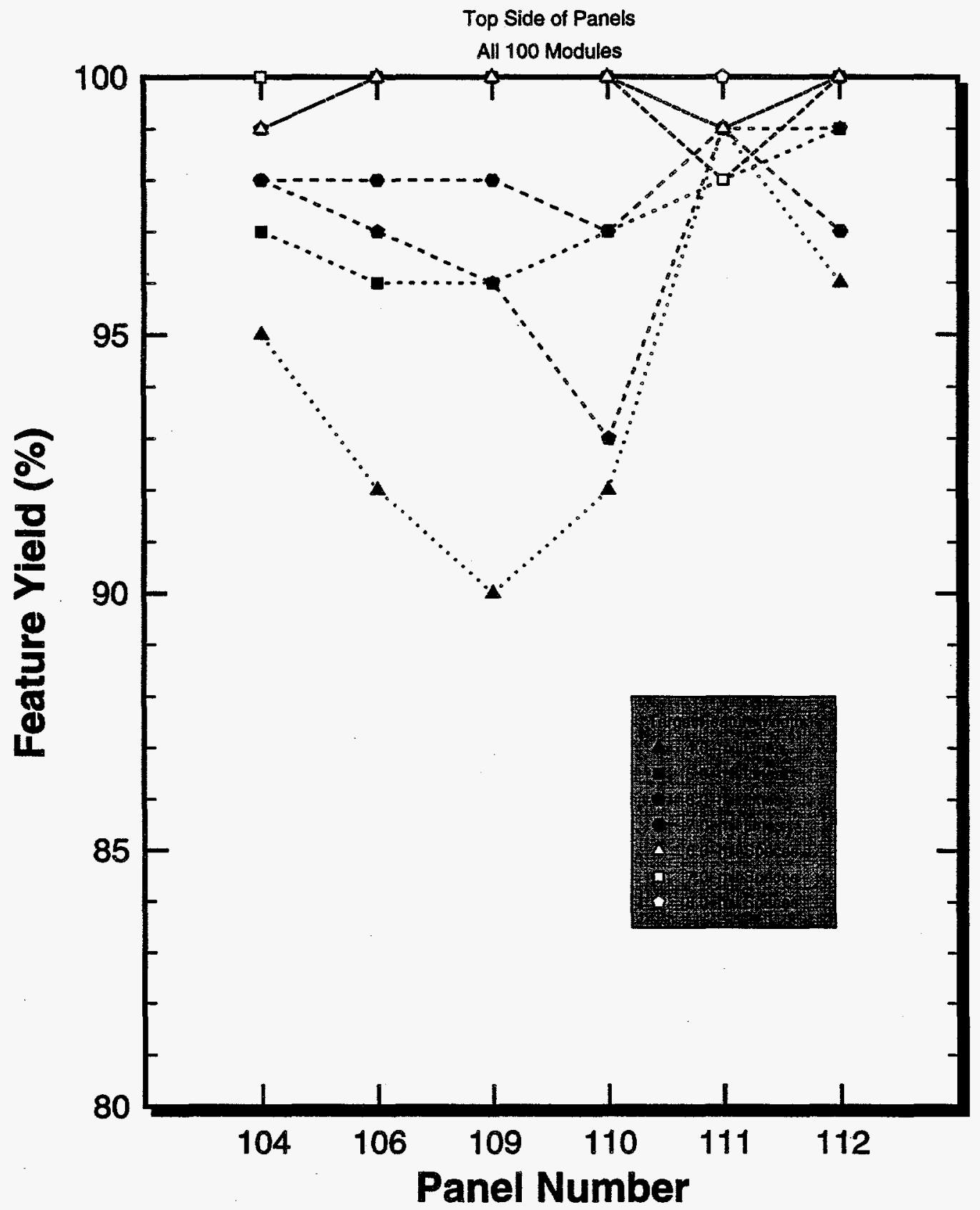

AlliodSignal FMBT

CAP Version 1.01 - AlliedSignal KCD pyield_tgrt

FL Etchant - Run a

Pattern: Multi-pitch November 25, 1996

Design: [5] 5 [6] 6 m 7 [8] Copyright 1 1995-1996 CAT inc. All Rights Reserved

${ }^{7}$ CAT, Inc., Conductor Analysis Technologies, Inc., Albuquerque, New Mexico. 


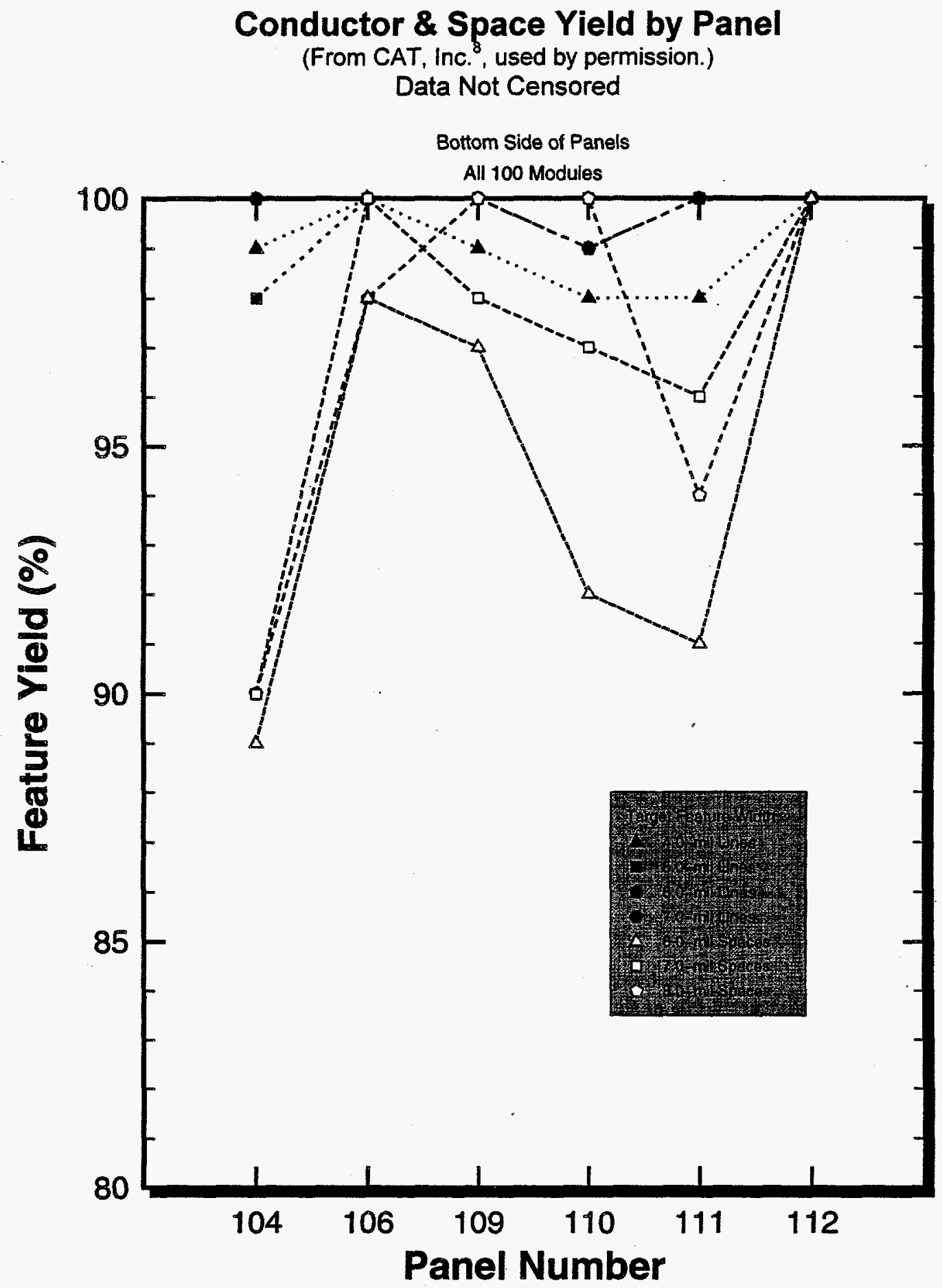

AlliedSignal FM\&T

FL Etchant - Run $\odot 60$

Pattem: Multi-pilch

CAP Version 1.01 - AlliedSignal KCD pyield_b.grt November 25, 1996 Copyright 0 1995-1996 CAT Ine. All Rights Reserved

${ }^{8} \mathrm{CAT}$, Inc., Conductor Analysis Technologies, Inc., Albuquerque, New Mexico. 


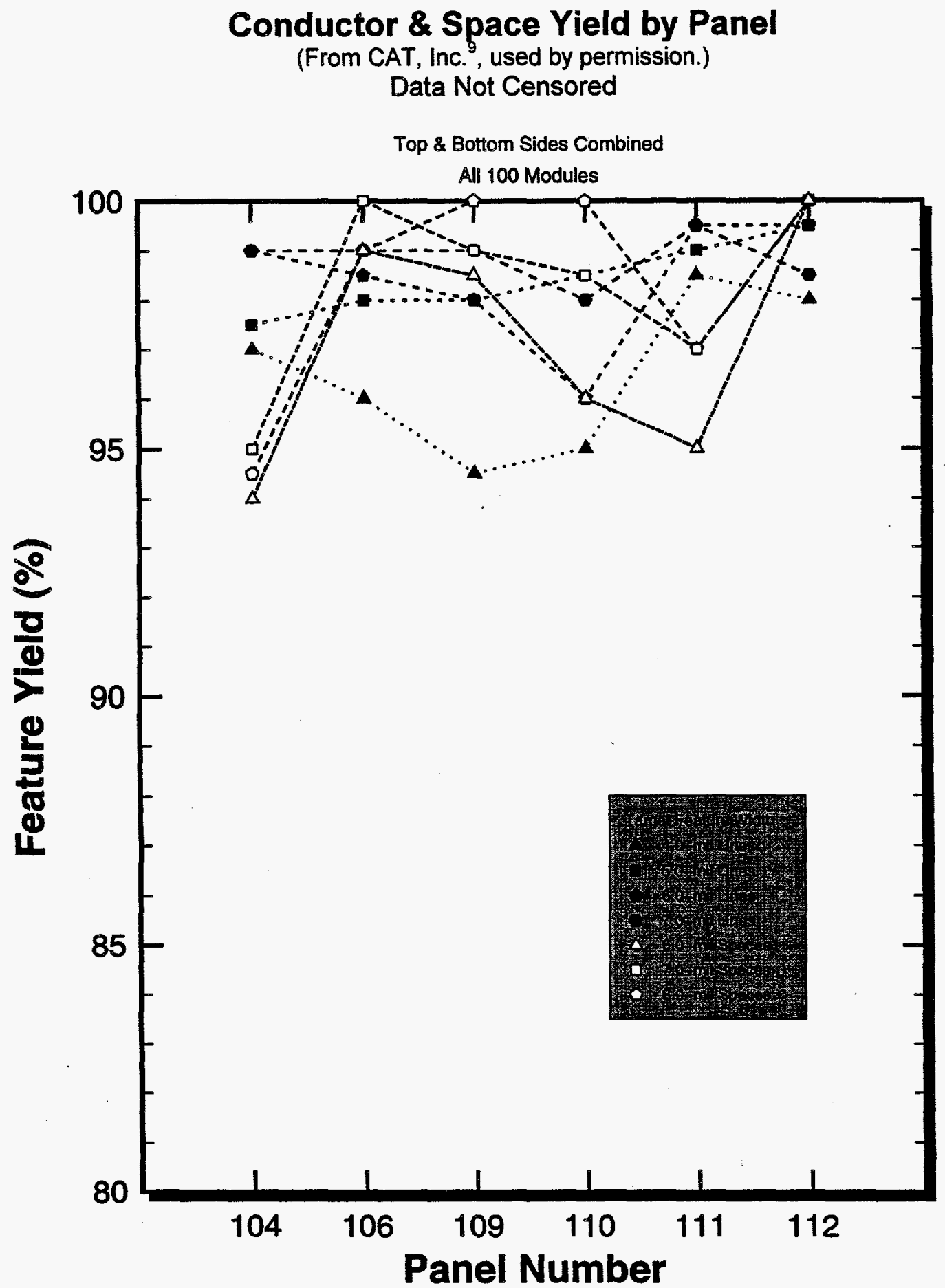

AlliedSignal FMET

FL Etchant - Run 00

Pattern: Multi-pitch

Design: [5] 5 [6] 6 [7] 7 [B]

CAP Version 1.01 - AlliedSignal KCD pyleld_a.grt November 25, 1996 Copyright 1995-1996 CAT inc. All Rights Reserved

${ }^{9} \mathrm{CAT}$, Inc., Conductor Analysis Technologies, Inc., Albuquerque, New Mexico. 